\title{
1936. La destrucción de los espacios y símbolos del culto católico en La Mancha*
}

\author{
Fernando del Rey Reguillo ${ }^{1}$ \\ Universidad Complutense de Madrid \\ freyregu@cps.ucm.es
}

RESUMEN: Apoyado en fuentes de archivo originales, en este artículo se analiza la oleada de iconoclastia que recorrió la retaguardia manchega - en concreto, la provincia de Ciudad Real-en el verano y otoño de 1936, tras el fracaso del golpe de Estado que dio pie a la guerra civil española. Se hace especial hincapié en el estudio de los tiempos y los actores que impulsaron esa oleada destructiva enmarcada en el proceso revolucionario que se ensayó, dirigido a crear un mundo nuevo bajo los auspicios del sueño igualitario alimentado por las corrientes obreristas imbuidas de esos afanes niveladores. En este proceso revolucionario se buscó explícitamente terminar con el poder cultural y simbólico que venía disfrutando la iglesia católica durante siglos. La singularidad de la provincia manchega radica en el hecho de que, a diferencia de otras zonas de España, aquella iconoclastia radical carecía de precedentes de importancia, pese a lo cual la oleada aniquiladora resultó contundente y se equiparó con los territorios de la retaguardia republicana que tenían una trayectoria anticlerical muy arraigada y antigua. El texto se complementa con un apéndice final pormenorizado donde se hace balance de los templos afectados y se mide el alcance de la devastación.

PALABRAS CLAVE: iconoclastia; sacrofobia; anticlericalismo; guerra civil española.

* AHN, CG: Archivo Histórico Nacional, Causa General (Madrid). AGHD: Archivo General Histórico de Defensa (Madrid). AMLS: Archivo Municipal de La Solana (Ciudad Real).

${ }^{1}$ ORCID iD: https://orcid.org/0000-0003-1138-1569.

Copyright: (C) 2020 CSIC. Este es un artículo de acceso abierto distribuido bajo los términos de una licencia de uso y distribución Creative Commons Reconocimiento 4.0 Internacional (CC-BY 4.0) 


\section{The destruction of spaces and symbols of the Catholic faith in La Mancha}

ABSTRACT: Based on archival sources, this article analyses the wave of iconoclasm that swept the rearguard of Castile La Mancha - and in particular the province of Ciudad Real-during the summer and autumn of 1936 following the failure of the coup d'état that led to the Spanish Civil War. Special emphasis is placed on the timing and the protagonists of this destructive wave, which took place within the framework of a revolutionary process fostered by working-class currents seeking to create a new, egalitarian world. This revolutionary process sought to destroy the cultural and symbolic power which the Catholic Church had enjoyed for centuries. The singularity of the province of Ciudad Real is that, in contrast to other areas of Spain, its radical iconoclasm was unprecedented. Despite this, the wave of destruction was formidable, comparable to that of territories characterized by a traditional and deep-seated anticlericalism. The appendix details the churches affected and the extent of the devastation.

KEY WORDS: Iconoclasm; sacrophobia; anticlericalism; Spanish Civil War.

CÓMO CITAR ESTE ARTÍCULO/CITATION: Rey Reguillo, Fernando del, «1936. La destrucción de los espacios y símbolos del culto católico en La Mancha», Hispania, 80/265 (Madrid, 2020): 563-596. https://doi.org/10.3989/hispania.2020.016.

\section{INTRODUCCIÓN}

Al poco de estallar la guerra civil tras el fracaso del golpe de Estado iniciado el 17-18 de julio de 1936, la demolición del orden social vigente —en el que la Iglesia todavía ocupaba un lugar central - fue la premisa obligada para construir el nuevo orden revolucionario que se puso en marcha en la España que resistió el avance de los rebeldes. Ello se hizo «a sangre y fuego», como predicaban los medios identificados con aquel proceso de cambio acelerado. $\mathrm{Su}$ repercusión inmediata fue la búsqueda del aniquilamiento físico del clero, uno de los fenómenos más impactantes entre los desarrollados en la zona republicana en los primeros meses del conflicto bélico, como testifica la abundante literatura disponible al respecto ${ }^{2}$. La estimación «clásica» fijó en 6.832 las víctimas de aquella masacre, repartidas entre 4.184 miembros del clero secular, 2.365 religiosos y 283 religiosas. Casi un millar de eclesiásticos fueron muertos en las dos primeras semanas del conflicto, en el mes de julio, y otros dos millares aproximadamente cayeron en el mes de agosto. Para finales de año ya

2 Véase, entre otros, ALBERTI, 2008. CÁRCEL ORTÍ, 1990; 1995; 2000; 2008. CASANOVA, 2001. CASTRO ALFÍN, 1997; 2005. CUEVA MERINO, 1998. SUÁREZ CORTINA, 2001; 2014. LEDESMA VERA, 2009; 2012. MARTÍN RUBIO, 2007. RAGUER, 2001. RANZATO, 1997. THOMAS, 2014. VINCENT, 2010.

Hispania, 2020, vol. LXXX, n. ${ }^{\circ}$ 265, mayo-agosto, págs. 563-596, ISSN: 0018-2141, e-ISSN: 1988-8368 https://doi.org/10.3989/hispania.2020.016 
habían sido asesinadas cerca del 90\% de las víctimas religiosas que se registraron a lo largo de la guerra civil ${ }^{3}$.

En el ámbito concreto de Ciudad Real, que es la provincia manchega a la que se ciñe este artículo, los religiosos muertos en julio sumaron 61 individuos: 57 pertenecientes al clero regular, 3 al clero secular y un seminarista, que en su conjunto representaron el $39 \%$ de todos los asesinados en aquellas dos semanas, un porcentaje enorme partiendo de que la población religiosa - en torno a un millar de personas entre curas, religiosos y monjas - apenas suponía el $0,20 \%$ de los habitantes de esta demarcación. Otros 80 religiosos murieron en agosto, 39 en septiembre, 20 en octubre, 22 en noviembre y 1 tan sólo en diciembre, momento en el cual — salvo alguna excepción aislada - se pueden considerar clausuradas las matanzas de clérigos en la provincia. A lo largo de la guerra fueron asesinados en total 212 religiosos avecindados en la zona (116 pertenecientes al clero regular y 96 al secular, todos varones a excepción de una monja franciscana), a los que habría que añadir 11 más procedentes de otras provincias, que fueron abatidos aquí ( 9 pertenecientes al clero regular y 2 al secular). Porcentualmente, sólo en lo que se refiere al clero secular, las víctimas religiosas de la violencia revolucionaria sumaron en la provincia manchega en torno al 39,5\% de las personas dedicadas al culto ${ }^{4}$.

Junto al aniquilamiento de la población religiosa, también se produjo el ataque masivo contra el patrimonio arquitectónico de la Iglesia (templos, conventos, retablos, imágenes y objetos de culto considerados sagrados por los católicos), en una suerte de ejercicio destructor que no tenía precedentes y que se reprodujo con milimétrica semejanza, una localidad tras otra, a lo largo y ancho de la España republicana. En este sentido, la provincia de Ciudad Real no constituyó ninguna excepción. La singularidad radicó aquí en que la tradición anticlerical no fue especialmente acusada antes de 1931, ni siquiera entre ese año y el inicio de la guerra, en marcado contraste con aquellas zonas donde tal práctica venía de lejos: Andalucía, Cataluña, Levante, Madrid, etc. ${ }^{5}$ La eliminación de los espacios, edificios e iconos sagrados de la Iglesia fue la fórmula utilizada por los revolucionarios de 1936 para mostrar a los creyentes la impotencia del Dios católico, sus ídolos y sus representantes en la tierra. Como en cualquier manifestación antirreligiosa y de iconoclastia a lo largo de los siglos, en aquella guerra civil la destrucción impune de la esfera sagrada del

${ }^{3}$ MONTERO, 1998: 761-762. MARTÍN RUBIO, 2001: 69 y ss., corrige ligeramente las cifras de Montero, dejándolas en 6.771, desglosadas en 1 administrador apostólico, 12 obispos, 288 religiosas, 2.373 religiosos, 4.011 sacerdotes y 86 seminaristas. Precisiones similares en LEDESMA VERA, 2009; 2012: 221-222 y ss., que apunta los tiempos de la mortandad indicados.

${ }^{4}$ REY REGUILLO, 2019. MONTERO, 1998: 763, suma 97 sacerdotes asesinados y eleva el porcentaje al $39,9 \%$.

${ }_{5}$ Como se evidencia en REY REGUILLO, 2009. 
enemigo buscó resaltar la superioridad del nuevo credo revolucionario ${ }^{6}$. Desde este punto de vista, la guerra civil española puede verse no ya como una guerra de religión - como una cruzada-, tal y como se pretendió en el bando insurgente al cabo de varias semanas tras el inicio del conflicto, sino como una guerra entre religiones contrarias y radicalmente enfrentadas, disputada en el ámbito de lo sagrado. De ahí que los actos anticlericales presentaran siempre un carácter marcadamente anti-ritual, una auténtica puesta en escena con una teatralidad inspirada en la misma liturgia y las ceremonias católicas ${ }^{7}$. En la perspectiva de los más radicales, el fin último de esa escalada desacralizadora buscó la erradicación del cristianismo para sustituirlo por las nuevas religiones políticas y revolucionarias ${ }^{8}$.

En cualquier tiempo y lugar, particularmente en las guerras de religión, las prácticas destructoras de edificios y la iconoclastia pretenden desestabilizar al enemigo. Por eso atentan contra objetos y casas dotados de un carácter intensamente emocional. «El objetivo de la actuación iconoclasta es el de significar un desprecio, el de lanzar un reto contra el orden simbólico de las cosas», contra los edificios, imágenes u objetos que representan el poder que se pretende derribar. La quema y/o demolición de los edificios religiosos y la iconoclastia buscan también convencer del derrocamiento definitivo de un régimen o una opción política que se consideran derrotados, llevando a cabo acciones absolutamente impensables bajo el imperio de la ley y el predominio de las anteriores referencias simbólicas. Sus artífices persiguen «quedarse completamente convencidos de la destrucción definitiva del antiguo orden». La consecuencia última de tal acción es la transgresión de todo tipo de ley, la consecución del sacrilegio más notorio. Con él se pretende humillar al prójimo en sus creencias más veneradas sin importar el daño causado ${ }^{9}$. La guerra civil española mostró como pocas guerras civiles del siglo XX el impacto de esas pulsiones destructoras, que en este caso se beneficiaron según los casos del pleno respaldo, el asentimiento más o menos cómplice o la dejación de funciones de buena parte de los poderes constituidos a escala local y provincial, sobre todo en los seis o siete primeros meses del conflicto. Frente a lo que a veces se afirma, el arrasamiento de la simbología y los espacios religiosos no fue fruto de la acción espontánea de turbas incontroladas, sino la consecuencia de la acción de minorías audaces vinculadas a las mismas organizaciones que se comprometieron en la lucha contra los sublevados y en la defensa de la República sostenida por

${ }^{6}$ Toda esta caracterización, en CUEVA MERINO, 1998: 281-282. También, LINCOLN, 1999. Para la destrucción del patrimonio, SAAVEDRA ARIAS, 2012; 2016, que se ciñe al caso de Cantabria.

7 DELGADO RUIZ, 1992.

8 GENTILE, 2000; 2001. PAYNE, 2006: 146.

9 Reflexión genérica sobre la iconoclastia, en BRAUD, 2006: 223-224. 
el Frente Popular. Bien es verdad que, aunque llegó muy tarde, a partir de 1937 el Gobierno republicano consiguió imponerse sobre los poderes locales y puso en marcha una política de protección y conservación del patrimonio histórico-artístico, incluyendo lo que quedaba del eclesiástico. Esto también se hizo efectivo, siquiera a una escala testimonial, en la provincia que nos ocupa ${ }^{10}$.

\section{SECUENCIA Y ALCANCE DE LA DESTRUCCIÓN PATRIMONIAL}

Sintomáticamente, a las pocas horas de tener noticias del golpe, los dirigentes locales - que no eran otros que los que se habían hecho con los ayuntamientos tras el triunfo de las izquierdas en las elecciones de febrero- dispusieron el cierre de las iglesias y prohibieron la celebración del culto y el toque de campanas. Sólo algún sacerdote mal informado o en exceso temerario osó desobedecer las órdenes de la autoridad, como el cura de Terrinches, Victoriano Sánchez-Camacho, que se atrevió a tocar a misa y a celebrarla en una fecha tan tardía como el 25 de julio, llevado de su celo por cumplir a toda costa el deber sacerdotal. Al día siguiente fue apresado, decretándose su traslado a la cárcel provincial. Meses después, el 10 de noviembre, el Tribunal Popular de la capital lo condenó a catorce años de prisión «por auxilio a la rebelión». Pero ese mismo día alguien decidió que la «justicia del pueblo» no podía asumir una sentencia de esa naturaleza, estimándola blanda, razón por la cual el sacerdote fue fusilado por la noche en el cementerio de Torralba de Calatrava, a escasos kilómetros de Ciudad Real. Y es que, puestos a trasgredir las normas, los únicos que podían hacerlo eran los que se veían a sí mismos como la vanguardia de la revolución. Sin réplica posible a su poder, ellos marcaban arbitrariamente las reglas del juego y ellos establecían quiénes podían transgredirlas y quiénes no. Mientras tanto, la iglesia parroquial de Terrinches resultó clausurada al tiempo que, conforme a un ritual escenificado en la casi totalidad de las iglesias de la provincia, las imágenes, los altares, el retablo, las ropas de culto y el órgano desaparecieron pasto de las llamas. Por su lado, los objetos sagrados que tenían algún valor se esfumaron como por ensalmo a manos de los incendiarios. Una vez vaciado, el templo se destinó a granero y cochera de la colectividad que se constituyó en las semanas siguientes. Tales destrozos se hicieron extensivos a las otras tres ermitas de la localidad ${ }^{11}$.

Como el destino de su sacerdote, lo sucedido con los templos de aquel pueblo no constituyó ninguna excepción. Más bien todo lo contrario. Con mayor o menor intensidad — sólo una cuestión de grado-, el destrozo, la

10 PRADO SÁNCHEZ-CAMBRONERO, 2018.

11 AHN, CG, leg. 1029, exp. 18, fs. 2, 9, 21-23. JIMÉNEZ MANZANARES, 1947: 193 194. MONTERO, 1998: 867. 
iconoclastia y la profanación de los espacios sagrados de los católicos fueron la norma en toda la provincia, a partir de una secuencia que se inició a las pocas horas de estallar la guerra. A su término, lo raro fue encontrar algún edificio religioso que se salvara de la quema o la destrucción. En un informe elaborado por el Obispado de Ciudad Real, fechado en diciembre de 1940, se brindó un balance de los daños causados en la provincia por la oleada iconoclasta durante la conflagración. En varios pueblos y la propia capital la destrucción de algunas iglesias fue completa, si por tal entendemos su incendio y el derribo de, al menos, una parte significativa del edificio (la torre, el tejado, algún muro...). Ejemplos al respecto los encontramos en Campo de Criptana (donde sólo quedaron los cimientos de la iglesia parroquial), Puertollano (la iglesia de la Virgen de Gracia) y La Solana, Membrilla y Manzanares (cuyas iglesias parroquiales y otros templos fueron incendiados), amén de varias ermitas y santuarios de menor importancia de otras localidades. Que la documentación de la sección Causa General del AHN no exageraba en este aspecto concreto se comprueba cuando se contrastan sus datos con los ofrecidos por los archivos municipales, las propias fuentes de la Iglesia y los testimonios orales. Al fin y al cabo, esa macro-investigación, puesta en marcha por la dictadura con fines punitivos al poco de concluir el conflicto bélico y que por ello mismo hay que manejar con prudencia, se nutrió con los informes que le suministraron las autoridades locales del momento, incluido el estamento religioso. Respecto a cuántos edificios fueron profanados y saqueados por dentro, con la consiguiente quema de imágenes, retablos y robo de los objetos de culto, los informes de la autoridad eclesiástica de posguerra resultan concluyentes:

Puede decirse que todos, tanto en la capital como en los pueblos. En los primeros días del Movimiento todas las iglesias fueron cerradas al culto e incautadas, entrando luego las turbas al saqueo y pillaje de los ornamentos y vasos sagrados y objetos del culto. Después las fueron destinando a refugio de evacuados que en gran número vinieron a Ciudad Real a la provincia [sic], garajes, depósitos de víveres.

La Catedral fue incautada y destinada primero a garaje y después a albergue de evacuados. Sus dependencias fueron ocupadas para oficinas de la Liga Masónica de defensa de los derechos del hombre, asistencia social y beneficencia.

La Iglesia parroquial de Santa Cruz de Mudela fue convertida en teatro. La de Madre de Dios a mercado público [sic] y muchas de otros pueblos a [sic] estos mismos usos u otros semejantes (la de Madre de Dios de Almagro).

Los edificios de los Conventos de uno y otro sexo corrieron la misma suerte que sus respectivas iglesias ${ }^{12}$.

${ }^{12}$ Informe del Vicario General, 23.12.1940 (AHN, CG, leg. 1033, exp. 3, fs. 15-16). Según MONTERO, 1998: 629 y CÁRCEL ORTÍ, 1990: 240, las iglesias totalmente destruidas en Ciudad Real fueron 6, mientras que todas las demás resultaron parcialmente devastadas, profanadas y saqueadas, habiéndose acabado igualmente con todo el ajuar litúrgico de la diócesis. 
El informe del Obispado no iba muy descaminado, aunque la cuantificación que se ha realizado aquí a partir de las fuentes disponibles - informes de procedencia local- es más precisa. Sin contar los oratorios particulares afectados, el total de edificios y locales religiosos (parroquias, ermitas, conventos, capillas...) golpeados por la pulsión anticlerical en la provincia fueron, al menos, 253, de los cuales 24 resultaron totalmente destruidos. En los demás, lo habitual fue arrasar el contenido de los templos, pero no tanto el continente. Es decir, se procedió con una celeridad inusitada a la quema, destrucción y robo de las imágenes y objetos de culto, retablos, altares, mobiliario, vestiduras sacerdotales, pavimento, enseres variados, etc. Una vez consumados el expolio y la destrucción, esos edificios corrieron la suerte más dispar. Según la información disponible, consta, además, que en 24 localidades desaparecieron por completo los archivos parroquiales. En 25, las pérdidas o quema de documentos eclesiásticos sólo fueron parciales y en otros 23 tales archivos no sufrieron daño alguno. Aunque en un primer momento no fueron objeto de especial atención, con el transcurso de la guerra los enseres relacionados con el patrimonio eclesiástico que más valor cobraron fueron las campanas. Se tiene constancia de que, al menos, fueron sustraídas de los templos y conventos de 21 localidades, no sin resistencias en algún caso particular ${ }^{13}$.

Que en la mitad de las poblaciones de la provincia se perdiera abundante documentación archivística de sus templos contrasta con el hecho de que los archivos públicos corrieran mejor suerte. Los papeles de los registros civiles, los juzgados, los archivos municipales e incluso los protocolos notariales, con algunas salvedades, se salvaron. Una de las principales excepciones la encontramos en Manzanares, donde, en la noche del 20 al 21 de julio, fue incendiado y parcialmente destruido el registro de la propiedad. Dentro del mismo partido judicial, lo cual no parece casual, aquella misma noche se inició la quema del archivo municipal y el registro civil en Membrilla, pueblo donde el predominio anarquista era incontestable. En Manzanares también había un núcleo anarquista fuerte, aunque no gozó del monopolio en el poder local de que hicieron gala sus compañeros de la localidad vecina. Pero que tal circunstancia - la correlación entre la presencia libertaria y la furia iconoclasta - no lo explica todo, lo demuestra el ejemplo de La Solana, otra localidad próxima, pero de abrumador predominio socialista. Aquí, unos días después de lo acontecido en Membrilla y Manzanares, el 31 de julio, fue incendiado y completamente destruido el archivo del juzgado, ocurriendo lo mismo el 2 de agosto con el protocolo notarial «para que no constase nada en documento alguno que de una manera directa o indirecta pudiera dar relación de propiedad o dominio $\rangle^{14}$. En

${ }^{13}$ Elaboración y cálculos propios a partir de los informes locales recogidos en AHN, CG, legs. 1027, 1028, 1029, 1030, 1031 y 1033. Véase el apéndice final.

${ }^{14}$ Las comillas referidas a La Solana, en ROMERO VELASCO, 1940: 124. 
otra localidad cercana a Manzanares, Arenas de San Juan, tuvo también lugar la destrucción parcial del archivo municipal y del registro civil, pero en este caso ello tuvo que ver con el importante enfrentamiento armado que se produjo el 23 de julio en ese pueblo, a raíz de la conformación de un foco rebelde que dio pie a una contundente respuesta miliciana lanzada desde los pueblos de alrededor y que, a la postre, se saldó con más de 40 muertos por parte de los insurrectos ${ }^{15}$. Después de todos estos sucesos, ocurridos a finales de julio o poco más tarde, el último caso relevante de documentación incendiada se produjo en Almagro, donde el 8 de septiembre fueron quemados sucesivamente los archivos judicial y municipal, el registro de la propiedad y la notaría. Significativamente, el mismo día se quemó el archivo del juzgado de paz de Bolaños, pueblo situado a escasos kilómetros del anterior. Por lo demás, sólo se perdió alguna documentación pública en los archivos municipales de Argamasilla de Calatrava, Corral y Villamayor, pueblos del partido de Almodóvar, y en los registros civiles de Malagón y Las Labores ${ }^{16}$.

La cronología de los asaltos a los edificios religiosos revela el sustrato revolucionario imperante en la cultura política de buena parte de la izquierda obrera antes del estallido bélico. Un porcentaje alto de los asaltos se sucedieron en los primeros días del conflicto, cuando todavía no se sabía que el golpe fuera a desembocar en una guerra larga y cruenta, dándose por sentado que la insurrección iba a fracasar, o al menos eso repetía la propaganda gubernamental. Un total de 34 pueblos de la provincia se vieron sacudidos por la furia iconoclasta en aquellas jornadas de violencia caliente, frente a 27 en agosto, 2 en septiembre, 3 en octubre, 5 en noviembre y 2 en diciembre. Aunque no se dispone de la cronología de 24 localidades, tan alto grado de concentración temporal de los ataques a los templos, la iconoclastia y los incendios en las dos semanas iniciales de la guerra denota de por sí cómo la pasión revolucionaria fijó enseguida cuáles eran los objetivos prioritarios. También resulta aleccionador que la acción destructora se concentrase esos días en los pueblos de cinco partidos judiciales: Alcázar de San Juan, Manzanares y Daimiel (situados en el cuadrante noreste de la provincia), Almodóvar del Campo y Almadén (en el cuadrante suroccidental). En los tres primeros, se aprecia una coincidencia clara con la cronología de la persecución del clero regular, desalojado a la fuerza de sus conventos y convertido al instante en una preciada pieza de caza. En los otros dos pueblos sin duda pesó la alarma generada por el encontronazo tan temprano que se produjo en Puertollano, el mismo 19 de julio, con la familia Cabañero al ir a detener a sus miembros. Este fue el primer foco rebelde detectado en la provincia que, pese a su escasa importancia, levantó una fuerte reacción por parte de las

15 Este caso se analiza en REY REGUILLO, 2019: 85-87.

16 AHN, legs. 1027, 1028, 1029, 1030, 1031 y 1033.

Hispania, 2020, vol. LXXX, n. ${ }^{\circ} 265$, mayo-agosto, págs. 563-596, ISSN: 0018-2141, e-ISSN: 1988-8368 https://doi.org/10.3989/hispania.2020.016 
milicias armadas y de la fuerza pública ${ }^{17}$. La impresión al contemplar aquellos acontecimientos es que se persiguió el rápido arrasamiento de cualquier símbolo católico presente en la esfera pública. Los afectados lo percibieron como si se tratase de una plaga de termitas cuyo fin expreso buscaba borrar todo rastro de la religión en los espacios abiertos $\mathrm{y}$, en buena parte, también en el ámbito privado ${ }^{18}$.

Ante la estupefacta mirada de los vecinos, el impulso incendiario adquirió tonos de inquietante espectáculo público en muchos sitios. Posiblemente, la localidad donde la fuerza anticlerical se manifestó de forma más contundente y temprana, a partir del día 21, fue Manzanares. Quince edificios religiosos se vieron afectados por el fuego destructor, cinco de ellos en su totalidad. Ni siquiera los oratorios privados eludieron la pira. Algo similar sucedió en Almagro, donde el fuego acabó con todo entre el 19 y el 23 de julio. Ningún edificio religioso se libró: la iglesia parroquial fue incendiada y otros 11 templos y dos conventos resultaron profanados y saqueados, con la correspondiente destrucción de su contenido e imágenes. Y lo mismo ocurrió en Daimiel por esos mismos días (10 de los 11 edificios religiosos quedaron completamente arrasados). En Santa Cruz de Mudela fue el 26 cuando se propagaron sin freno las llamas a nueve edificios de esa índole tras izar una bandera roja en la torre de la iglesia parroquial. A partir del 18 de agosto, la iglesia homónima de Campo de Criptana fue primero incendiada y luego destruida, procediéndose a su demolición con dinamita y barrenos, algo similar a lo ocurrido con la ermita de San Sebastián, de la que no quedaron ni los cimientos. Lo más llamativo y espectacular fue que todo sucediera tan rápido, para asombro, regocijo o estupor de los presentes, que de todo hubo ${ }^{19}$. Como se refleja en el apéndice final, el destrozo arquitectónico, material y artístico causado al patrimonio religioso de la provincia manchega - como en la mayor parte de la retaguardia republicana-, un patrimonio acumulado celosamente durante siglos, fue inconmensurable e imposible de valorar en su justa medida.

\section{LOS AGENTES DE LA REVOLUCIÓN ANTICATÓLICA}

Para el caso de La Solana se ha podido precisar con más detalle la secuencia incendiaria y los autores directos de la misma. Ya el 20 de julio, a los tres días

17 ALÍA MIRANDA, 2017: 78. REY REGUILLO, 2019: 78-80.

18 ALÍA MIRANDA, 2017: 78. REY REGUILLO, 2019: 78-80.

19 AHN, CG, leg. 1029, exp. 3, fs. 11 y 359-363 (Manzanares); leg. 1028, exp. 18, fs. 9, 20 y 458 ; leg. 1033, exp. 3, fs. 20-21 y 37-38 (Almagro); leg. 1028, exp. 25, fs. 12, 306-309, 312 у 1033, exp. 3, f. 133 (Daimiel); leg. 1030, exp. 4, fs. 6, 14-15 y 94. 
del golpe, el concejal Deogracias Maroto pidió a la alcaldía que se quitasen las cruces que todavía figuraban en algunas fachadas. Desde meses atrás, este concejal venía insistiendo en la necesidad de suprimir la simbología religiosa en todos los espacios públicos del pueblo. Pero el día 23 se dio un salto más que espectacular al proceder los revolucionarios a la destrucción del valioso retablo del altar mayor de la iglesia parroquial, junto con el coro, el órgano, los altares, las imágenes de los santos y vírgenes y el archivo, del que no se salvó ni un solo papel. Dos días después, el 25, se prendió fuego a la imponente cúpula de la torre, la más alta de la provincia — dejándola completamente desmochada—, y al tejado del resto del templo, del que sólo se mantuvieron en pie las murallas, «quedando convertido el hermoso edificio y la esbelta torre en la más horrorosa figura». El fuego acabó incluso con el reloj, que era propiedad del ayuntamiento. En la siguiente jornada, el 26 de julio, fueron incendiadas otras dos iglesias (las del Cristo del Amor y Convento de los Trinitarios) y tres ermitas (Santa Quiteria, San Sebastián y El Calvario) ${ }^{20}$.

Un testigo de excepción - Enrique Carretero Espinar- dio pistas en la posguerra sobre cómo se procedió a prender fuego a la parroquia, porque él mismo se halló inmerso en la operación, a la fuerza o voluntariamente. De su relato se desprende que no fue una multitud informe y anónima la que tomó la iniciativa, sino personas concretas con militancias igualmente reconocibles (en ese momento, casi todos socialistas). En realidad, eso fue lo que sucedió en la mayor parte de las localidades, si no en todas. Frente al mito de las «masas», «el pueblo» o los «trabajadores» incontrolados —imbuidos de odio a la religión y a los curas por sus afrentas desde tiempo inmemorial-, cabe subrayar que la oleada iconoclasta fue auspiciada por grupos minoritarios conscientes, radicalizados y de firmes convicciones ideológicas, procedentes de las distintas organizaciones obreras y, en menor medida, del republicanismo de izquierdas. El detalle de que el bidón de la gasolina con el que se prendió fuego al principal templo de la localidad lo sacaran del propio ayuntamiento - situado justo enfrente de la parroquia, al otro lado de la plaza mayor - es todo un indicio en la clarificación de quiénes tomaron las decisiones y quiénes fueron los responsables de aquella iniciativa. De los siete individuos que citó Enrique Carretero, en un testimonio que se reproduce a continuación, el segundo, el cuarto y el quinto fueron dirigentes del Comité de Defensa; el tercero ejercía de escribiente en el consistorio; mientras que el primero y los dos últimos no pasaron de milicianos de base en esos momentos y después. Obviamente, se tienen noticias convincentes de que en

${ }^{20}$ Véase Auditoría del Ejército de Ocupación, AMLS, caja 444 y Actas del Pleno, 20.07.1936, AMLS, caja 1427. AHN, CG, leg. 1029, exp. 1, fs. 3 y 84-86. ROMERO VELASCO, 1940: 121-123, autor que fija el incendio de las ermitas y la Iglesia del Cristo del Amor el día 25, y la iglesia del Convento en varias fechas sucesivas de 1937.

Hispania, 2020, vol. LXXX, n. ${ }^{\circ} 265$, mayo-agosto, págs. 563-596, ISSN: 0018-2141, e-ISSN: 1988-8368 https://doi.org/10.3989/hispania.2020.016 
los incendios participaron bastantes más personas, pero los que constan debieron ser algunos de los que llevaron la voz cantante:

Que la noche que quemaron las iglesias, se encontraba paseando por la plaza en unión de Ángel Pacheco Barrera y les ordenó Antero Alhambra que fueran al Ayuntamiento, de donde salió el Antero en unión de Felipe Nieva Carralero entregándole al procesado un bidón de gasolina, que tuvo que llevar a la iglesia en donde vio regar este líquido por el interior, mandándole entonces que se retirara, viendo al poco tiempo que salía un grupo entre los que iban Gabriel Valencia, Bernardo [García] Abadillo, uno apodado el «Chato el Alhambreño» [Ramón Álamo Moreno] y Adolfo Díaz Albo, empezando enseguida a arder la iglesia ${ }^{21}$.

La confesión de uno de los aludidos en la cita, Felipe Nieva, coincide en puntos esenciales y en varios nombres con el cuadro trazado por el testimonio anterior. Cabe retener el dato no menor de que Nieva era militante de Unión Republicana, en contraste con el resto de los citados, de militancia socialista:

Que la noche que incendiaron las Iglesias, y a eso de las diez, se encontraba el procesado en el Ayuntamiento habiendo ya terminado su tarea y a punto de marcharse a su casa, y entonces vio a Antero Alhambra, Enrique Carretero Espinar y otro apodado Chaquetilla, que cree se llama Ángel Pacheco, sacar un bidón de gasolina que había en el Ayuntamiento y llevarlo rodando hacia la Sacristía de la Iglesia. Que el procesado marchó a acostar casi enseguida levantándose al día siguiente temprano cuando ya empezaba a salir humo de la Iglesia, y al ver aquello se acercó a la buñolería de Dolores Pardilla aconsejándole que cerrara la puerta para evitar cualquier contacto con el incendio a punto de ocurrir ${ }^{22}$.

Varios testimonios señalaron al citado Ángel Pacheco Barrera (a) Chaquetilla, «escopetero» desde los primeros días, como el autor material del rociado de la gasolina en la iglesia parroquial, apuntando que él mismo se jactó de aquel acto en varias ocasiones durante la guerra. No obstante, el hecho de no ocupar cargos de relevancia en el engranaje de poder revolucionario, como el marcharse voluntario al frente a los pocos días, lleva a la conclusión de que Chaquetilla debió ser un simple mandado: «Este sujeto fue el que roció con gasolina con una regadera nuestra hermosa Iglesia Parroquial», «por habérselo oído directamente comentar», «y así mismo le vio haciendo guardia en los

${ }^{21}$ Declaración de Enrique Carretero Espinar, Manzanares, 4.07.1939, AGHD, Madrid, leg. 3485/6153. Este individuo fue también miliciano y, poco después, secretario de las Juventudes Libertarias, y de la Federación de Trabajadores de la Tierra desde 1938. Pero no parece que en las jornadas de julio hubiera asumido todavía la militancia anarquista; hasta entonces había pertenecido al Partido Socialista y a la UGT. Se le acusó de haber ideado, junto con su hermano Eduardo, el procedimiento para destruir la torre de la iglesia parroquial.

${ }^{22}$ Declaración de Felipe Nieva Carralero, Manzanares, 8.07.1939, AGHD, Madrid, leg. $4354 / 1004 / 10$. 
alrededores de la Iglesia, por donde no dejaban circular a persona que no fuera de confianza de los rojos, la mañana del incendio de las Iglesias, cuando aún se encontraba ardiendo la Parroquial $\rangle^{23}$.

Por encima del arrasamiento del patrimonio religioso, que de por sí causó una profunda conmoción en el mundo conservador, lo que posiblemente dolió más a los católicos y a sus líderes espirituales —en cuanto que supuso un ataque frontal a sus creencias - fue el carácter ofensivo, de burla y mofa, que tuvieron aquellas prácticas de irreverencia, en abierta violación de la libertad de conciencia y de los espacios, los símbolos y los rituales que aquéllos consideraban sagrados. Lo reflejó bien el informe del obispado de 1940:

Aunque los sacerdotes procuraron en los primeros momentos evitar la profanación de las sagradas formas (y muchos lo consiguieron poniendo en grave riesgo su vida) se cometieron horrendos sacrilegios:

En Alcázar de San Juan se apoderaron de Ellas y entre burlas y blasfemias las comieron simulando la Sagrada Comunión entre unos y otros.

En Valdepeñas fueron arrojadas por el suelo y acaso en lugares inmundos, capitaneados los sacrílegos por el dirigente principal del pueblo [Félix Torres Ruiz] y algunos jóvenes. En Tomelloso y Pedro Muñoz sufrieron igual género de profanación.

La profanación de las Sagradas imágenes fue general tanto en la capital como en los pueblos. Al entrar al saqueo de los templos eran arrojadas al suelo desde sus altares, y unas veces dentro del templo y otras fuera eran hechas pedazos a golpe de martillo, arrastradas por las calles, expuestas en los caminos y entradas de los pueblos como objetos de ludibrio o quemadas en las plazas entre burlas y blasfemias.

Es rara la parroquia o iglesia que haya podido salvar sus imágenes de la furia iconoclasta de los profanadores, sin exceptuar las más veneradas por su historia o por su arte y devoción.

Se dice que con la imagen de la Ssma. Virgen del Prado, patrona de la capital, se llegó a hacer una parodia execrable, fingiendo casarse un hombre con ella y terminando por arrojarla al templo desde la hornacina de su camarín.

La imagen de talla de Jesús Nazareno, atribuida a Montañés o a un discípulo suyo, de la Parroquia de San Pedro y a la que se profesaba mucha devoción en Ciudad Real, fue hecha pedazos y después quemada.

En Alcázar de San Juan desapareció la imagen de Santa Victoria, que contenía restos del cuerpo de la Santa.

Lo mismo decimos de muchísimos relicarios con el Lignum Crucis y reliquias de Santos, sin que podamos precisar las circunstancias de su desaparición. El relicario más preciado de la Diócesis, por el número y calidad de las reliquias traídas de Roma a fines del siglo XVIII, estaba en la parroquia de Infantes y ha sido destruido totalmente. Conservaba un trozo del Lignum Crucis, que era objeto de gran veneración ${ }^{24}$.

${ }^{23}$ Testimonios de Pedro Mayoralas Márquez, Mariano Reguillo Morales y Vicente García Bustos, entre otros, AGHD, Madrid, leg. 2468/6101.

${ }^{24}$ Informe del Vicario General de Ciudad Real, AHN, CG, leg. 1033, exp. 3, fs. 7-16. 
De los 98 municipios con que contaba la provincia de Ciudad Real en los años 30, se carece de información sobre las acciones destructoras e iconoclastas en cuatro de ellos, de lo que cabría deducir que no se registraron, pero tal extremo no se puede afirmar con rotundidad. Esos pueblos fueron Albaladejo, Arroba de los Montes, Fuente el Fresno y Villarta de San Juan. En el resto, se cumplió a pie juntillas la secuencia, como si previamente hubieran acordado sus protagonistas la puesta en escena del mismo guion. Con acuerdo o no, lo cierto es que no hubo improvisación entre los grupos que alentaron aquellos hechos. La percepción predominante en la cosmovisión conservadora - de donde proceden la mayoría de las imágenes que siguen - es la de unas muchedumbres desaforadas irrumpiendo en los templos sin freno alguno. Por supuesto, retratadas negativamente: «Abriendo las Iglesias pasó la chusma en tropel cogiendo con violencia las joyas de sus imágenes» (Moral de Calatrava) ${ }^{25}$. Al igual que en Tomelloso: «Un grupo numeroso de personas mayores y menores asaltaron la Iglesia Parroquial, robando cuanto de valor o aprovechamiento existía en la misma y haciendo mofa de las imágenes las sacaron quemándolas con altares y ornamentos en el centro de la Plaza pública». Y en Socuéllamos: «Numerosos individuos de esta localidad, destacados por sus ideas marxistas y de las peores condiciones, asaltaron la Iglesia Parroquial de esta villa, cuya llave tenían en su poder, e hicieron numerosísimos actos de vandalismo, destruyendo a disparos de pistola las imágenes que en ella había $»^{26}$.

Sin embargo, en contraste con esas imágenes imprecisas, sabemos que a la cabeza de los grupos incendiarios, como se ha indicado para La Solana, figuraban a menudo los líderes revolucionarios locales, dirigentes de los comités de defensa y de las milicias. Actos de tal gravedad no podían efectuarse sin contar con el asentimiento de los cabecillas de la revolución. No se trataba de individuos «incontrolados» como tantas veces se ha escrito sin fundamento. En algún caso, incluso, el liderazgo no se improvisó esos días, sino que venía de atrás. Por ejemplo, Marino Sáiz Sánchez, vecino de Almodóvar del Campo que había sido elegido diputado a Cortes en las elecciones de febrero, al parecer se puso en primera línea cuando hubo que acometer el saqueo y quema de las iglesias del lugar. En Poblete fueron el juez municipal y el alcalde los que dieron toda clase de facilidades a los incendiarios: «Sobre las cinco de la tarde del expresado día, el Juez Municipal de esta villa Don Antolín Navarrete Trotiaga, que como Jefe Revolucionario tenía las llaves de la Iglesia parroquial de Sta. María Magdalena, se las entregó al $2^{\circ}$ Alcalde Don Moisés Martín Fragoso, procediéndose seguidamente por las hordas Marxistas a la destrucción y quema de imágenes y ropas del culto sagrado». Pero incluso si se trataba de grupos pequeños el desenlace siempre era idéntico, la quema de todos los enseres al aire libre

\footnotetext{
25 AHN, CG, leg. 1030, exp. 3.

26 AHN, CG, leg. 1029, exp. 29 (Socuéllamos) y exp. 30 (Tomelloso).
} 
y con frecuencia a plena luz del día, como en Alamillo: «Sobre las ocho de la mañana del indicado día varios individuos capitaneados y dirigidos por Regino Redondo Hiruela penetraron en la única Iglesia de este pueblo, haciendo en su parte exterior una gran hoguera donde fueron arrojadas cuantas imágenes había en el Templo así como sus retablos y objetos religiosos incluso rompiendo las pilas de bautismo y agua bendita hasta que todo quedó convertido en cenizas». En el momento previo a la quema, lo habitual fue la escenificación del escarnio con los santos, tal como en Argamasilla de Calatrava donde «fueron quemados y pisoteados en su totalidad $\rangle^{27}$.

Así pues, por lo general, las autoridades locales no se inhibieron e incluso facilitaron que las imágenes y objetos de culto acabaran en la hoguera. Pero se dio alguna excepción. En Aldea del Rey «se acordó el cierre de las Iglesias, dando facilidades al vecindario para que se llevaran las imágenes y objetos de culto, recogiendo piadosamente tales objetos sagrados la mayoría de la población, entre ellos algunos familiares de los dirigentes rojos.» Si bien al final todo quedó en vana ilusión, en un espejismo temporal. Con motivo de una visita a la localidad de varias mujeres del Socorro Rojo de Puertollano para realizar una colecta, al entrar en una casa advirtieron la presencia de una imagen procedente de la Iglesia. Tal evidencia les pareció intolerable. Entonces, «la cogieron y la quemaron obligando a las demás personas que tenían imágenes a que las entregaran para quemarlas $\rangle^{28}$. En Poblete, donde algunas imágenes se salvaron del incendio inicial, sucedió algo parecido. En un gesto compasivo, un miliciano que se hallaba de guardia, Cecilio Sánchez López, a escondidas de sus jefes mientras estos saqueaban la Iglesia, dio la imagen de San Antonio a la vecina Antonia Muñoz y la de San Luis Gonzaga a Mar Fragoso, que las escondieron hasta el final de la guerra. Pero la imagen de San José corrió peor suerte. Entregada a Lucía Patón, «al llegar con ella a su casa su hermano Gabino Patón, Presidente de la Casa del Pueblo, la amenazó y cogiendo la imagen la llevó a puntillazos a la hoguera que ardía a la puerta de la Iglesia $\rangle^{29}$. En Torralba de Calatrava, José Orovio Díaz Moreno, directivo destacado de la UGT y concejal, se distinguió también entre los que profanaron y destruyeron imágenes, «mereciendo destacarse el hecho de haber colgado en un árbol de la plaza una imagen pequeña del Niño Jesús y con una pistola la estuvo disparando tiros hasta que la destrozó $\rangle^{30}$.

En otro orden de cosas, llevan razón quienes cuestionan la vieja interpretación de que la autoría de los actos de irreligión en la guerra civil fueron

${ }^{27}$ AHN, CG, leg. 1027, exp. 9 (Poblete) y exp. 13 (Alamillo); leg. 1028, exp. 3 (Almodóvar) y exp. 4 (Argamasilla).

28 AHN, CG, leg. 1028, exp. 2.

29 AHN, CG, leg. 1027, exp. 9.

${ }^{30}$ Informe de la alcaldía, s. f., AHN, CG, leg. 1032, exp. 3, f. 702. 
responsabilidad exclusiva o prioritaria de los anarquistas ${ }^{31}$. Ciertamente, en la provincia manchega esa interpretación tan reduccionista no encuentra respaldo empírico, siquiera porque la mayoría del obrerismo militaba en el socialismo y porque también hubo republicanos de izquierda - menos, ciertamente- que se implicaron en la persecución religiosa. El anarquismo era una fuerza marginal en este territorio, aunque no dejó de experimentar una cierta expansión durante el conflicto. Pero una expansión bastante artificial en tanto que vino dada por la acogida masiva de gentes de derechas en sus filas. El fenómeno respondió a una especie de do ut des. A los anarquistas les interesaba el incremento de su militancia a efectos representativos en los centros de poder y decisión de la retaguardia; por su parte, los derechistas dieron ese paso para encontrar resguardo y protección a la sombra de los libertarios. Con todo, en la búsqueda de los responsables de la violencia y la iconoclastia anticlerical, ni siquiera cabe responsabilizar al conjunto del socialismo, que en sí mismo era una corriente fragmentada en diversas ramas diferenciadas por su dispar grado de radicalización ${ }^{32}$.

En cualquier caso, por encima de las siglas, lo que resulta claro es que la quema de las iglesias y la iconoclastia respondió a la acción de personas y grupos concretos, para nada anónimos ni carentes de liderazgo. Grupos que en la mayor parte de las ocasiones integraron individuos procedentes del vecindario, aunque también hubo salvedades al respecto ${ }^{33}$. La capacidad de convocatoria de los mismos varió sustancialmente y no resulta fácil determinarla, entre otras razones porque muchos de los congregados lo hicieron más como espectadores, curiosos o jaleadores circunstanciales que como revolucionarios conscientes. La presencia, a veces, de abultadas multitudes en los rituales iconoclastas respondía a esa circunstancia: el grueso de los presentes se arracimaba como espectador más que como agente destructor, labor que correspondía a las minorías audaces y muy convencidas del paso que estaban dando. Lo que sí prueban las fuentes es que no faltó la presencia de mujeres en los espacios que acogieron las llamas o los saqueos, por más que fueran en general en posiciones subalternas y a remolque de los hombres ${ }^{34}$. Como, por ejemplo, en Alhambra, pueblo en el que los informes de posguerra señalaron a varias de ellas situadas en primera fila. Y en Campo de Criptana, en donde saltan los nombres de aguerridas milicianas, como Otilia Bonardell, Juana

31 Por ejemplo, THOMAS, 2014: 99 y ss.

${ }^{32}$ CUEVA MERINO, 1998: 265-266 y 268, indica que El Socialista, en manos de los prietistas, criticó esporádicamente a los partidarios de la «limpieza de la retaguardia» desde finales de septiembre de 1936. La tesis sobre los anarquistas la corrobora para toda Castilla-La Mancha MARTÍN NIETO, 2019.

33 Coincido con LEDESMA VERA, 2009: 30-32; 2012: 234.

${ }^{34}$ Coincido con THOMAS, 1914: 145-156. 
Tapia, Josefa Palomino, Amadea Martín, Anselma Quintanar, Ramona Simón y María Plaza. Por su parte, en Abenójar consta que, de 43 vecinos detectados como presentes - o participantes - en el asalto a la iglesia parroquial, 28 eran féminas. ${ }^{35}$

Aun así, conviene remarcar que los impulsos destructores no vinieron sólo de los protagonismos y decisiones locales. La irrupción de agentes externos a la localidad se ha detectado en nueve casos, esto es, aproximadamente un $10 \%$ del total, pero pudieron ser más. En San Lorenzo de Calatrava, por ejemplo, a los vecinos congregados para destruir las imágenes se sumaron «unos 15 o 20 individuos que vinieron de Mestanza». En la comarca del Campo de Montiel se mostraron muy activos los hombres del Batallón Félix Torres, de Valdepeñas, cuya larga sombra se vislumbró, cuando menos, en Infantes, Santa Cruz de los Cáñamos y Villamanrique. Pero la palma se la llevaron varios pueblos del partido judicial de Piedrabuena, en el noroeste de la provincia, el más aislado por su particular orografía y carencia de comunicaciones. Así, en Alcoba de los Montes, los saqueos de la parroquia, el incendio de las imágenes y la sustracción de las campanas las realizaron forasteros, milicianos «desconocidos» «que llegaron de Ciudad Real y que hasta es posible que vinieran autorizados para hacerlo». En Arroba, en septiembre de 1936, «un dirigente rojo de Alcolea pretendió destruir las imágenes de la Iglesia parroquial, sin que tal impío propósito se llevase a efecto, por apresurarse los mismos elementos rojos de la localidad a retirarlas de los altares, depositándolas en la sacristía, en donde se encontraron en la liberación». Aunque en noviembre los paisanos ya no pudieron evitar que una decena de milicianos de la capital se llevaran las campanas. Al negarse el presidente del Comité de Defensa «a efectuar su entrega le fue entregado un oficio del Gobernador, autorizándolos, no pudiendo oponerse». La misma impotencia vecinal ante los forasteros que se presentaron a efectuar el expolio de las campanas se apreció en otros pueblos de la zona (Fontanarejo, Navalpino y Retuerta del Bullaque). Resulta curiosa la observación de cómo en algunas localidades, por lo general pequeñas, la solidaridad vecinal todavía funcionó — por encima de los alineamientos ideológicos - frente a los agentes externos en medio del fragor de la guerra civil. En esos casos, la incautación de las campanas fue concebida por los vecinos como el expolio de un bien común y por eso lo intentaron evitar, con las autoridades «rojas» en primera línea ${ }^{36}$.

${ }^{35}$ AHN, CG, leg. 1028, exp. 1, f. 8 (Abenójar); leg. 1029, exp. 25, f. 10 (Tomelloso) y exp. 9, f. 8 (Alhambra).

36 AHN, CG, leg. 1028, exp. 11, f. 6 (San Lorenzo); leg. 1029, exp. 14, f. 7 (Infantes), exp. 17, fs. 6 y 19, y exp. 21, f. 19 (Villamanrique); leg. 1030, exp. 11, f. 7 (Alcoba), exp. 12, f. 6, exp. 11, f. 6 y 16 (Arroba), exp. 15, f. 29 (Navalpino) y exp. 21, f. 8 (Retuerta).

Hispania, 2020, vol. LXXX, n. ${ }^{\circ}$ 265, mayo-agosto, págs. 563-596, ISSN: 0018-2141, e-ISSN: 1988-8368 https://doi.org/10.3989/hispania.2020.016 


\section{Prácticas de irReVERENCIA ICONOCLASTA}

Junto a la quema y la rotura de imágenes o la incautación y expolio de enseres, no faltaron los gestos irreverentes y carnavalescos, acompañados a veces de toques escabrosos, en sí mismos sobrecogedores y dolorosos para los creyentes. En Porzuna «quemaron los cuadros religiosos, se mofaron de los Santos antes de destruirlos poniéndoles bigotes y cosas análogas. La Virgen del Rosario, Patrona de esta villa, la colgaron en una de las paredes que sostenían las campanas y una vez colgada en el campanario, le sacaron los ojos». En Brazatortas, además de disparar a las imágenes — práctica muy común—, «un grupo de milicianos llevó su impiedad al extremo de pasearse por las calles revestidos de ornamentos sacerdotales llevando en la mano el Cáliz de la Iglesia Parroquial donde bebían vino todos». En Alhambra, junto a los consabidos disparos, arrastraron las imágenes «atadas con sogas». El ritual procesional se concebía a modo de réplica de la ocupación católica del espacio público en fechas tan señaladas como las romerías, las comuniones o la semana santa. Naturalmente, el maestro de ceremonias, la coreografía y los cánticos eran ahora muy distintos, de acuerdo a la religión revolucionaria concebida como alternativa radical al culto cristiano. Por poner otro ejemplo, en Torrenueva, según Segundo Toledo Velasco, teniente de alcalde que acudió a esa reunión, la destrucción de las iglesias y ermitas «fue un acuerdo del ayuntamiento» ${ }^{37}$ : «Los Sagrados Corazones, atados previamente del cuello, fueron arrastrados por la población haciendo las paradas consiguientes, se estacionaba el público y se procedía a cantar la Internacional por un grupo de chicos y una persona de mayor edad que era precisamente el dirigente de la comparsa $)^{38}$.

Como corrían tiempos bélicos, pero no por ello se renunciaba a la fiesta y la chirigota, menudearon también los guiños marciales. Así, en Corral de Calatrava vistieron las imágenes «de milicianos rojos» y las pusieron «en las entradas del pueblo simbolizando una guardia». En Santa Cruz de Mudela, tras sacar las estatuas de sus nichos y arrojar alguna a un pozo, «las alinearon en la carretera de Madrid a Cádiz, colgándole a la imagen de San Francisco de Asís una escopeta y en uno de los brazos una pistola». Pero en otros lugares les daban un aspecto más práctico, como aquellos milicianos de Ciudad Real que «utilizaban a manera de delantales cuando cocinaban casullas y otros objetos religiosos». No menos pragmático, a la par que irreverente, fue el gesto de un vecino de Fernán Caballero, Calixto Marín Dorado, que con una imagen de madera maciza se hizo «un comedero para los cerdos». Mientras, en San Carlos del Valle, como el movimiento iconoclasta comenzó echando de la casa

\footnotetext{
${ }^{37}$ AGHD, Madrid, leg. 26636/6257.

38 AHN, CG, leg. 1030, exp. 19 (Porzuna) y exp. 5 (Torrenueva); leg. 1028, exp. 3 (Brazatortas); y leg. 1029, exp. 9 (Alhambra).
} 
rectoral al párroco, que se refugió en la del sacristán, le quemaron su biblioteca particular y se comieron "cuantos víveres tenía en su casa»" ${ }^{39}$.

Desde la perspectiva de los católicos más celosos de sus creencias, tan grave o más que todo lo anterior fue constatar cómo no faltaron personas que, habiendo estado muy cerca de la religión y de la Iglesia, ahora militaban en el bando de la revolución. Una actitud de esa índole la encarnó, por ejemplo, Santiaga Núñez Villanueva (a) la monja, comunista y concejal en Calzada de Calatrava, «gran propagandista en mítines y actos públicos de la causa marxista», aunque, a todas luces, el informante de posguerra no se privó de cargar las tintas al calificarla de «mala persona» y señalar que «hizo burla de la religión profanando los hábitos de monja que profesó». Alguno incluso la acusó de propagar «el amor libre y otras cosas por el estilo». Sin embargo, otras fuentes de la época dibujan un cuadro más complejo, el de una mujer que había sido novicia pero que nunca profesó, comprometida con los desvalidos, que intentó montar un hospital para los heridos de guerra en el pueblo y que brindó ayuda a muchas personas de derechas cuando la precisaron ${ }^{40}$.

Por lo demás, resulta indiscutible que la guerra supuso un gigantesco trauma para el mundo católico, especialmente para los creyentes que permanecieron en la retaguardia republicana y asistieron impotentes a los acontecimientos, tanto por las muertes de los religiosos como por la demolición y arrasamiento de sus espacios y símbolos sagrados. Pero también por verse privados de los ritos, ceremonias y costumbres que desde tiempo inmemorial habían ordenado sus vidas hasta ese momento. Al prohibirse el culto católico y quedar sin sus guías espirituales, no sólo dejaron de asistir a misa, recibir el bautismo, tomar la comunión o contraer matrimonio confesional, es que ante el trance de la muerte ocurrió otro tanto. El sustitutivo lo encontraron, cuando eso fue posible, en ritos laicos escenificados sobre la marcha, como celebrar los entierros con el féretro envuelto en la bandera del sindicato o partido de turno, arropados los familiares por los compañeros de trabajo. Pero, aun así, el trago de enterrar a los deudos sin tener a mano un sacerdote no dejó de ser una experiencia muy amarga y traumática para los católicos ${ }^{41}$.

\section{Conclusión}

A la vista del cuadro trazado, se comprende la ingente tarea de reconstrucción que tuvo que afrontar la acción católica en la posguerra, aquí como en

${ }^{39}$ AHN, CG, leg. 1027, exp. 1 (Ciudad Real), exp. 5 (Fernán Caballero); leg. 1028, exp. 9 (Corral); leg. 1029, exp. 5 (San Carlos del Valle); y leg. 1030, exp. 4 (Santa Cruz de Mudela).

${ }^{40} \mathrm{La}$ imagen negativa, en Informe de la alcaldia, 7.06.1946, AHN, CG, leg. 1032, exp. 3, f. 366. La imagen compleja y el «amor libre», AGHD, Madrid, leg. 3384/2219.

${ }^{41}$ Entrevista con Jesús del Rey García, La Solana, 30.12.1987, que vio enterrar a su abuela con tales carencias, adornado el féretro con la bandera de la UGT. 
todas las provincias que no cayeron en manos de los sublevados en los primeros meses del conflicto. En su afán por recuperar los espacios de culto y dotarse del personal suficiente para ejercerlo, se admitía que era una «labor extremadamente difícil, puesto que la pasada guerra de liberación, durante toda la cual estuvo esta provincia bajo dominio marxista, destrozó cuanto hasta su comienzo estaba organizado y la privó de la mayoría de los dirigentes y de una gran parte del clero». Pese a la multiplicación de vocaciones que se vivió en el clima de cruzada forjado tras el triunfo de los ejércitos de Franco, el número de sacerdotes disponibles en los años cuarenta fue muy reducido, apenas 131 en la provincia de Ciudad Real todavía mediada la década, cifra claramente insuficiente para retomar con solvencia la acción pastoral. Por no hablar de la carencia de guías espirituales verdaderamente aptos y preparados: «Se pasa actualmente por la triste realidad de no poder prestar casi ninguna ayuda a la Jerarquía cuando, por la falta de sacerdotes, más precisa le es» ${ }^{42}$.

Aun así, a pesar y por encima de los destrozos acarreados, la fobia anticlerical de los años treinta y la brutalidad desplegada durante la guerra civil contra los católicos produjeron un resultado paradójico en tanto que, lejos de afirmar la secularización y erradicar la presencia de la religión en el espacio público, generaron el efecto opuesto, el reforzamiento de la movilización clerical. De hecho, dado el resultado de la guerra, la Iglesia alcanzó un ascendiente sobre el Estado y una influencia sobre la sociedad infinitamente superiores a los que había disfrutado esta institución antes de la llegada de la República. Un ascendiente y una influencia mucho mayores incluso que los conseguidos en los años dorados de la Dictadura de Miguel Primo de Rivera (1923-1930) ${ }^{43}$.

De este modo, junto con las matanzas indiscriminadas de religiosos, la destrucción del patrimonio eclesiástico y la iconoclastia escenificada traumáticamente en la retaguardia republicana - que en su fondo persecutorio y su hostilidad no tuvieron nada de mito - constituyeron una dimensión esencial de la dialéctica entre revolución y contrarrevolución vinculada al desarrollo de la guerra civil, singularmente en los primeros meses del conflicto. Este combate dio argumentos a los sublevados — con el beneplácito de la mayor parte de la jerarquía episcopal - para presentarse como los adalides de la religión frente a sus enemigos seculares. A la postre, además, la afirmación en esa causa funcionó como una pieza esencial en la institucionalización y preservación a largo plazo de la dictadura franquista como un régimen nacionalcatólico, una vez abandonada, por inconveniente, la mímesis fascista inicial. Fue así como la dictadura pudo considerarse a sí misma, y venderse al exterior, como la vanguardia y reserva moral de occidente en la preservación de la Cristiandad, no sin contar con la comprensión y el aplauso de muchos católicos de otros países,

\footnotetext{
42 Anuario Estadístico de la Provincia, 1947: 477 y 482-484.

${ }^{43}$ PÉREZ LEDESMA, 2001: 269.
} 
aterrorizados ante lo ocurrido en las secuencias revolucionarias inauguradas en el verano de 1936. En su fondo aniquilador, la ofensiva contra la religión católica y sus mentores desarrollada en España al calor del proceso revolucionario de retaguardia sólo encuentra paralelismos con lo ocurrido en Rusia durante su guerra civil (1918-1922) o en la Cristiada Mexicana (1926-1929). Pretender negar el perfil persecutorio de aquellos hechos —un auténtico cataclismo nihilista - y blanquearlos como un conflicto político-religioso más, sólo refleja las anteojeras ideológicas y el sectarismo militante de quien se empeña en tan absurda posición.

\section{APÉNDICE. TEMPlos AFECTAdos POR LA ICONOCLASTIA EN LA PROVINCIA DE Ciudad Real (1936)}

\begin{tabular}{|c|c|c|c|}
\hline Localidad & Fecha & Edificio & Descripción \\
\hline \multicolumn{4}{|c|}{ Partido judicial de Alcázar de San Juan } \\
\hline \multirow[t]{3}{*}{$\begin{array}{l}\text { Alcázar de San } \\
\text { Juan }\end{array}$} & ¿? & $\begin{array}{l}\text { Conjunto de templos y } \\
\text { edificios religiosos }\end{array}$ & $\begin{array}{l}\text { Las iglesias no fueron incendiadas, pero sí } \\
\text { profanadas y convertidas en almacenes y cuarteles, } \\
\text { siendo destruidas las imágenes y objetos de culto. }\end{array}$ \\
\hline & 21.07.36 & Convento de los Franciscanos & $\begin{array}{l}\text { Sólo quedaron en pie las paredes y la techumbre. } \\
\text { Altares, retablos y púlpito fueron quemados. } \\
\text { Pavimento levantado. Robo de los vasos sagrados. }\end{array}$ \\
\hline & 21.07.36 & Convento de los Trinitarios & $\begin{array}{l}\text { Quedó convertido en cuartel de milicias y almacén } \\
\text { de víveres. Todos los objetos religiosos fueron } \\
\text { destrozados: órgano, retablos, altares, bancos, } \\
\text { confesionarios e imágenes. }\end{array}$ \\
\hline $\begin{array}{l}\text { Argamasilla de } \\
\text { Alba }\end{array}$ & ¿?.08.36 & $\begin{array}{l}\text { Parroquia de San Juan } \\
\text { Bautista }\end{array}$ & $\begin{array}{l}\text { Tras su incendio, sólo quedaron en pie las paredes } \\
\text { del edificio. Se hicieron pedazos las imágenes y los } \\
\text { objetos de culto. Se quemó el archivo. Las } \\
\text { campanas fueron transportadas a Sagunto y } \\
\text { fundidas. Los objetos de valor se los llevó a Ciudad } \\
\text { Real el líder socialista Manuel Carnicero } \\
\text { Fernández. }\end{array}$ \\
\hline \multirow[t]{2}{*}{$\begin{array}{l}\text { Campo de } \\
\text { Criptana }\end{array}$} & 18.08 .36 & Iglesia parroquial & $\begin{array}{l}\text { Se incendió y destruyó el templo, con su torre, } \\
\text { previo saqueo y destrucción de imágenes y objetos } \\
\text { de culto, incluido un retablo de Berruguete y el } \\
\text { órgano. Después fue demolido con dinamita y } \\
\text { barrenos. También se destruyó el archivo parroquial } \\
\text { por completo. }\end{array}$ \\
\hline & 19.08.36 & Ermita de la Madre de Dios & $\begin{array}{l}\text { Fueron saqueados todos los pasos de las } \\
\text { procesiones de Semana Santa, destruidos y } \\
\text { quemados en las afueras del pueblo. La ermita fue } \\
\text { convertida en una fragua. }\end{array}$ \\
\hline
\end{tabular}




\begin{tabular}{|c|c|c|c|}
\hline Localidad & Fecha & Edificio & Descripción \\
\hline & 19.08 .36 & Ermita de la Veracruz & $\begin{array}{l}\text { También fueron destruidos aquí sus pasos y las } \\
\text { imágenes. Fue convertida en un almacén de } \\
\text { muebles incautados. }\end{array}$ \\
\hline & 19.08 .36 & Ermita de la Virgen de la Paz & Idéntico balance que en el caso anterior. \\
\hline & 19.08.36 & Ermita de las Angustias & Idéntico balance que en el caso anterior. \\
\hline & 19.08.36 & Ermita de Santa Ana & Idéntico balance que en el caso anterior. \\
\hline & 19.08.36 & Ermita de San Sebastián & $\begin{array}{l}\text { Idéntico balance, salvo que esta ermita fue también } \\
\text { demolida hasta los cimientos. }\end{array}$ \\
\hline & 19.08.36 & $\begin{array}{l}\text { Antiguo Convento de } \\
\text { Carmelitas }\end{array}$ & $\begin{array}{l}\text { El edificio fue incendiado, con el saqueo y } \\
\text { destrucción de todas las imágenes y profanación de } \\
\text { ropas y objetos de culto. }\end{array}$ \\
\hline & 19.08 .36 & $\begin{array}{l}\text { Santuario del Cristo de } \\
\text { Villajos }\end{array}$ & $\begin{array}{l}\text { Patrono de la villa. Su imagen fue fusilada y hecha } \\
\text { astillas y el santuario reducido a ruinas por el } \\
\text { incendio. La madera de los retablos se empleó en } \\
\text { «quemar hornos de yeso». }\end{array}$ \\
\hline & 19.08 .36 & $\begin{array}{l}\text { Santuario de la Virgen de } \\
\text { Criptana }\end{array}$ & $\begin{array}{l}\text { Patrona de la villa. Su imagen fue fusilada y hecha } \\
\text { astillas y el santuario reducido a ruinas por el } \\
\text { incendio. }\end{array}$ \\
\hline & 20.08 .36 & Capilla del Cementerio & $\begin{array}{l}\text { Quema y destrucción de imágenes, enseres y todo } \\
\text { vestigio religioso. }\end{array}$ \\
\hline Herencia & $\begin{array}{l}\text { Varias } \\
\text { fechas sin } \\
\text { especificar }\end{array}$ & $\begin{array}{l}\text { Iglesia parroquial, Convento } \\
\text { de la Merced y Ermitas de } \\
\text { Nuestra Señora de la } \\
\text { Concepción, Cristo de la } \\
\text { Misericordia, San José y } \\
\text { Nuestra Señora de la } \\
\text { Encarnación, y otras varias } \\
\text { capillas más sin especificar }\end{array}$ & $\begin{array}{l}\text { Profanación y destrucción de imágenes y enseres. } \\
\text { La iglesia de los mercedarios fue despojada de } \\
\text { retablos, altares, imágenes y objetos de culto. Sólo } \\
\text { quedaron los muros y las puertas. Las campanas } \\
\text { fueron también sustraídas. La casa residencial se } \\
\text { dedicó a hospital de sangre. }\end{array}$ \\
\hline Pedro Muñoz & ¿?.07.36 & $\begin{array}{l}\text { Iglesia parroquial, Ermita de } \\
\text { Nuestra Señora de los Ángeles } \\
\text { y Ermita de San Miguel }\end{array}$ & $\begin{array}{l}\text { Los asaltos tuvieron lugar en los primeros días de la } \\
\text { guerra, destrozándose e incendiándose los altares, } \\
\text { las imágenes, objetos de culto y el archivo } \\
\text { parroquial. La parroquia fue convertida en Casa del } \\
\text { Pueblo. A los dos meses fueron derribadas las } \\
\text { campanas de la torre y enviadas a Sagunto para } \\
\text { fundirlas. }\end{array}$ \\
\hline Puerto Lápice & 28.07.36 & $\begin{array}{l}\text { Iglesia parroquial y Ermita de } \\
\text { San José }\end{array}$ & $\begin{array}{l}\text { Fueron profanados ambos edificios, destruyéndose } \\
\text { las imágenes y objetos de culto. }\end{array}$ \\
\hline Socuéllamos & 10.08 .36 & Iglesia parroquial & $\begin{array}{l}\text { Se destruyeron y se disparó contra las imágenes y } \\
\text { se arrojó el órgano desde el coro. Saquearon la } \\
\text { sacristía. Se apoderaron de las vestiduras } \\
\text { sacerdotales, de la custodia y objetos de culto; el } \\
\text { retablo quedó también completamente destruido. } \\
\text { Pero el registro parroquial no sufrió daños. }\end{array}$ \\
\hline
\end{tabular}




\begin{tabular}{|c|c|c|c|}
\hline Localidad & Fecha & Edificio & Descripción \\
\hline \multirow[t]{5}{*}{ Tomelloso } & 26.07.36 & Iglesia parroquial & $\begin{array}{l}\text { Sobre las dos de la tarde se asaltó el templo, } \\
\text { destrozando todos los objetos artísticos y de culto; } \\
\text { las imágenes, altares y ornamentos se sacaron a la } \\
\text { plaza y, tras mofarse de ellos, se incendiaron } \\
\text { seguidamente. Sólo quedó el edificio desmantelado } \\
\text { y muy deteriorado. También se llevaron las } \\
\text { campanas de la torre y remataron la cruz grande } \\
\text { situada en la cúpula del templo. El edificio se } \\
\text { dedicó a depósito de víveres. }\end{array}$ \\
\hline & 26.07 .36 & Iglesia de San Francisco & $\begin{array}{l}\text { Se destrozó todo lo que había dentro y se quemó en } \\
\text { la vía pública. Luego el edificio fue demolido por } \\
\text { orden de las autoridades. }\end{array}$ \\
\hline & 26.07.36 & Ermita del Cristo del Calvario & $\begin{array}{l}\text { Destrozaron todos los enseres y la destinaron a } \\
\text { vivienda particular. }\end{array}$ \\
\hline & 26.07 .36 & Capilla del Hospital Asilo & Se destruyeron las imágenes y ornamentos. \\
\hline & 26.07.36 & $\begin{array}{l}\text { Colegio de las Hermanas de } \\
\text { San Vicente de Paúl }\end{array}$ & $\begin{array}{l}\text { Se destruyeron e incendiaron las imágenes, muebles } \\
\text { y enseres. El edificio se destinó para las milicias y } \\
\text { luego para vivienda. }\end{array}$ \\
\hline \multicolumn{4}{|c|}{ Partido judicial de Almadén } \\
\hline \multirow[t]{2}{*}{ Agudo } & ¿?.07.36 & Iglesia parroquial & $\begin{array}{l}\text { Sustrajeron todas las alhajas, vasos sagrados y } \\
\text { ornamentos de valor. Quemaron libros y enseres. } \\
\text { Incluso desaparecieron las baldosas, cristalería, } \\
\text { puertas, ventanas, barandas, sillería y el pico de la } \\
\text { torre. También se llevaron las campanas. Quedó } \\
\text { destruido la mayor parte del archivo parroquial. La } \\
\text { iglesia se convirtió sucesivamente en Casa del } \\
\text { Pueblo, salón de baile, garaje-taller y depósito de } \\
\text { madera. }\end{array}$ \\
\hline & ¿?.07.36 & $\begin{array}{l}\text { Ermitas de Nuestra Señora de } \\
\text { la Estrella, del Santísimo y de } \\
\text { San Miguel }\end{array}$ & $\begin{array}{l}\text { Destrucción de todo, incluidos los retablos e } \\
\text { imágenes. Los edificios quedaron muy deteriorados. }\end{array}$ \\
\hline Alamillo & 3.08 .36 & Iglesia parroquial & $\begin{array}{l}\text { En la parte exterior de la iglesia hicieron una gran } \\
\text { hoguera con las imágenes, retablos y objetos } \\
\text { religiosos. Se rompieron las pilas del bautismo y } \\
\text { agua bendita hasta que todo quedó convertido en } \\
\text { cenizas. Después, el templo se utilizó de almacén de } \\
\text { abastos, alojamiento de prisioneros y fuerzas del } \\
\text { Ejército, incluso como cuadra de caballos. }\end{array}$ \\
\hline Almadén & ¿7.36? & Todas las iglesias & $\begin{array}{l}\text { Destrucción y saqueo de todas las iglesias, } \\
\text { quemando las imágenes. En cambio, el archivo } \\
\text { parroquial apenas sufrió desperfectos. }\end{array}$ \\
\hline Almadenejos & 23.07.36 & Iglesia parroquial & $\begin{array}{l}\text { Sacaron las imágenes y los objetos de culto y los } \\
\text { quemaron en la plaza pública. El registro parroquial } \\
\text { se salvó (no así el de la parroquia de la aldea de } \\
\text { Fontanosas»). }\end{array}$ \\
\hline
\end{tabular}




\begin{tabular}{|c|c|c|c|}
\hline Localidad & Fecha & Edificio & Descripción \\
\hline Chillón & ¿?.08.36 & $\begin{array}{l}\text { Iglesia parroquial de San Juan } \\
\text { Bautista y Ermita del Santo } \\
\text { Cristo }\end{array}$ & $\begin{array}{l}\text { Se robaron los objetos de culto y se destruyeron los } \\
\text { templos citados. }\end{array}$ \\
\hline Guadalmez & ¿?.08.36 & Iglesia parroquial & $\begin{array}{l}\text { A mediados de agosto se presentaron «las hordas» y } \\
\text { se cometieron toda clase de desmanes con las } \\
\text { imágenes, retablos y vestiduras sacerdotales. El } \\
\text { archivo parroquial fue destruido en su casi totalidad. }\end{array}$ \\
\hline Saceruela & 28.07.36 & Iglesia parroquial & $\begin{array}{l}\text { Fueron quemadas las imágenes y destruidos los } \\
\text { objetos de culto en la plaza. }\end{array}$ \\
\hline $\begin{array}{l}\text { Valdemanco del } \\
\text { Esteras }\end{array}$ & ¿? & $\begin{array}{l}\text { Iglesia parroquial de Nuestra } \\
\text { Señora del Valle }\end{array}$ & $\begin{array}{l}\text { Se procedió a la quema de los santos. Se utilizó } \\
\text { como Casa del Pueblo y matadero }\end{array}$ \\
\hline \multicolumn{4}{|c|}{ Partido judicial de Almagro } \\
\hline \multirow[t]{4}{*}{ Almagro } & 19.07.36 & $\begin{array}{l}\text { Iglesia parroquial de la Madrid } \\
\text { de Dios }\end{array}$ & $\begin{array}{l}\text { Tras su incendio, quedó destruida interiormente por } \\
\text { completo. Después fue convertida en mercado. }\end{array}$ \\
\hline & 23.07.36 & $\begin{array}{l}\text { Otros templos: San Bartolomé, } \\
\text { San Blas, San Agustín, Santa } \\
\text { Ana, San Juan, San Ildefonso, } \\
\text { La Magdalena, Santiago, } \\
\text { Ermita de Nuestra Señora de } \\
\text { las Nieves, Convento de las } \\
\text { Dominicas y Capilla del Santo } \\
\text { Cristo de la Salud }\end{array}$ & $\begin{array}{l}\text { Saqueo y destrucción de altares y quema de } \\
\text { imágenes de las iglesias. }\end{array}$ \\
\hline & 23.07 .36 & Convento de los Franciscanos & $\begin{array}{l}\text { El edificio quedó completamente destrozado, sin } \\
\text { puertas ni ventanas ni cristales, y del mobiliario no } \\
\text { quedó nada. Los tejados, deshechos. Arrancaron } \\
\text { hasta el pavimento del entarimado. No dejaron } \\
\text { tampoco objetos de culto. El cementerio lo } \\
\text { sembraron y arrancaron multitud de árboles del } \\
\text { huerto. Después sirvió de refugio para los } \\
\text { evacuados de otras provincias. }\end{array}$ \\
\hline & 25.07.36 & Convento de los Dominicos & $\begin{array}{l}\text { Destrucción de todos los objetos de culto, altares, } \\
\text { retablos e imágenes, que fueron quemados. La } \\
\text { iglesia quedó convertida en dormitorio para } \\
\text { dementes. Más tarde fue refugio de evacuados de } \\
\text { Córdoba y Extremadura. Luego, la Diputación } \\
\text { instaló un Hospital-Manicomio. }\end{array}$ \\
\hline Bolaños & ¿?.08.36 & $\begin{array}{l}\text { Conjunto de templos y } \\
\text { edificios religiosos }\end{array}$ & $\begin{array}{l}\text { Fueron destruidos cuantos objetos de culto, } \\
\text { imágenes y altares existían en las iglesias. En los } \\
\text { primeros días de septiembre fue destruido el } \\
\text { archivo parroquial «casi en su totalidad». }\end{array}$ \\
\hline $\begin{array}{l}\text { Calzada de } \\
\text { Calatrava }\end{array}$ & $\begin{array}{l}18,24 \mathrm{y} \\
25.07 .36\end{array}$ & $\begin{array}{l}\text { Ermitas de San Sebastián, San } \\
\text { Antón, San Isidro, San } \\
\text { Francisco y del Salvador del } \\
\text { Mundo, capilla del } \\
\text { Cementerio e Iglesia } \\
\text { parroquial }\end{array}$ & $\begin{array}{l}\text { Fueron incendiadas y saqueadas las imágenes, } \\
\text { objetos de culto y joyas de todos esos templos. En } \\
\text { febrero de } 1937 \text { sustrajeron las seis campanas de la } \\
\text { iglesia parroquial, otra de la Ermita de San Isidro, } \\
\text { otra del Salvador y otra del Cementerio. Se robaron } \\
\text { varios tomos del Registro parroquial. }\end{array}$ \\
\hline
\end{tabular}




\begin{tabular}{|c|c|c|c|}
\hline Localidad & Fecha & Edificio & Descripción \\
\hline \multirow[t]{2}{*}{$\begin{array}{l}\text { Granátula de } \\
\text { Calatrava }\end{array}$} & ¿? & Iglesia parroquial & $\begin{array}{l}\text { Se destrozaron todas las imágenes, altares, } \\
\text { ornamentos y órgano. Se hizo desaparecer todas las } \\
\text { campanas, excepto la del reloj de la torre. El } \\
\text { archivo fue destruido. Se arrancaron todas las } \\
\text { cruces que desde tiempo inmemorial existían en } \\
\text { determinados puntos del pueblo. La iglesia fue } \\
\text { destinada a establo de caballos }\end{array}$ \\
\hline & ¿? & Ermita del Cristo & Fue demolida hasta sus cimientos. \\
\hline \multirow[t]{2}{*}{$\begin{array}{l}\text { Pozuelo de } \\
\text { Calatrava }\end{array}$} & 6.09 .36 & Iglesia parroquial & $\begin{array}{l}\text { Destrucción de todas las imágenes y objetos de } \\
\text { culto, incendiadas a las afueras de la población. } \\
\text { Posteriormente, fueron destruidos los altares y la } \\
\text { mayoría de los retablos. Del archivo parroquial } \\
\text { desaparecieron varios legajos. }\end{array}$ \\
\hline & ¿?.09.36 & $\begin{array}{l}\text { Ermita de la Virgen de los } \\
\text { Santos }\end{array}$ & $\begin{array}{l}\text { Situada a } 12 \mathrm{kms} \text {. del pueblo, fue destrozada la } \\
\text { imagen de la Virgen. }\end{array}$ \\
\hline $\begin{array}{l}\text { Valenzuela de } \\
\text { Calatrava }\end{array}$ & 24.08.36 & $\begin{array}{l}\text { Iglesia parroquial y Ermita del } \\
\text { Santo Cristo }\end{array}$ & $\begin{array}{l}\text { Destrucción de las imágenes, objetos y ornamentos } \\
\text { de culto. En la quema fue destruido todo el archivo } \\
\text { parroquial y su registro. }\end{array}$ \\
\hline \multicolumn{4}{|c|}{ Partido judicial de Almodóvar del Campo } \\
\hline Abenójar & 21.07 .36 & $\begin{array}{l}\text { Iglesia parroquial Na Sra. de la } \\
\text { Asunción }\end{array}$ & $\begin{array}{l}\text { Saqueo, destrucción e incendio de las imágenes y } \\
\text { objetos de culto y quema de la iglesia. Destrucción } \\
\text { del archivo parroquial en su totalidad. }\end{array}$ \\
\hline Aldea del Rey & ¿?.07.36 & Iglesia parroquial & $\begin{array}{l}\text { Se saqueó la casa del párroco y se incautaron las } \\
\text { imágenes y objetos de culto por el vecindario. } \\
\text { Posteriormente, se ordenó su quema. La iglesia } \\
\text { quedó destrozada por haber alojado en ella a los } \\
\text { evacuados. Desparecieron varios libros y } \\
\text { documentos del archivo parroquial. }\end{array}$ \\
\hline \multirow[t]{2}{*}{$\begin{array}{l}\text { Almodóvar del } \\
\text { Campo* }\end{array}$} & 23.07.36 & Iglesia parroquial & $\begin{array}{l}\text { Saqueo, quema y destrozo de las imágenes, sillería, } \\
\text { órganos, pulpitos, objetos de culto y campanas. } \\
\text { Desaparecieron varios libros del archivo parroquial. }\end{array}$ \\
\hline & 23.07 .36 & $\begin{array}{l}\text { Iglesias del Carmen y Ermitas } \\
\text { del Beato Juan Bautista de la } \\
\text { Concepción, Santísima } \\
\text { Trinidad, San Antón, San José, } \\
\text { San Sebastián, Santa Brígida, } \\
\text { del Calvario y de San Isidro }\end{array}$ & $\begin{array}{l}\text { Saqueo, quema y destrozo de imágenes, mobiliario } \\
\text { y objetos de culto. Pérdidas parciales o totales de } \\
\text { los archivos parroquiales de las aldeas de } \\
\text { Tirteafuera, Retamar, Veredas, Minas de Horcajo y } \\
\text { Viñuela. }\end{array}$ \\
\hline $\begin{array}{l}\text { Argamasilla de } \\
\text { Calatrava }\end{array}$ & ¿?.07.36 & Las dos Iglesias Parroquiales & $\begin{array}{l}\text { Fueron quemados y destruidos en su totalidad los } \\
\text { santos, imágenes y objetos de culto. El archivo } \\
\text { parroquial conservó todos los libros de partidas. }\end{array}$ \\
\hline Brazatortas & ¿?.08.36 & Iglesia parroquial & $\begin{array}{l}\text { Saqueo, destrozo y quema en el campo de las } \\
\text { imágenes y objetos de culto, haciendo toda clase de } \\
\text { mofas. Dispararon contra las imágenes. El archivo } \\
\text { parroquial fue destruido en su totalidad. }\end{array}$ \\
\hline
\end{tabular}




\begin{tabular}{|c|c|c|c|}
\hline Localidad & Fecha & Edificio & Descripción \\
\hline Cabezarados & 23.07 .36 & Iglesia parroquial & $\begin{array}{l}\text { Saqueo y destrozos de imágenes y objetos de culto. } \\
\text { Los sacaron a la plazuela de la iglesia y se mofaron } \\
\text { de ellos. El } 26 \text { fueron rociados con gasolina y } \\
\text { quemados a las afueras de la población. El archivo } \\
\text { parroquial fue quemado en la plaza de la villa; se } \\
\text { salvaron algunos libros del registro eclesiástico. }\end{array}$ \\
\hline $\begin{array}{l}\text { Cabezarrubias } \\
\text { del Puerto }\end{array}$ & ¿? & Iglesia parroquial & $\begin{array}{l}\text { Saqueo y destrucción de imágenes y objetos de } \\
\text { culto. Destrucción completa del archivo parroquial. }\end{array}$ \\
\hline $\begin{array}{l}\text { Caracuel de } \\
\text { Calatrava }\end{array}$ & ¿? & Iglesia parroquial & $\begin{array}{l}\text { Destrozo de las imágenes y objetos de culto. } \\
\text { Desaparecieron los altares y ornamentos. El registro } \\
\text { parroquial no sufrió daños. }\end{array}$ \\
\hline $\begin{array}{l}\text { Corral de } \\
\text { Calatrava** }\end{array}$ & ¿?.07.36 & Conjunto de iglesias y templos & $\begin{array}{l}\text { Fueron desmantelados, totalmente destruidos y se } \\
\text { quemaron los retablos, imágenes y objetos de culto, } \\
\text { previa mofa de los mismos. Las campanas las } \\
\text { hicieron pedazos para metralla. Desaparecieron } \\
\text { varios libros del archivo parroquial. }\end{array}$ \\
\hline \multirow[t]{2}{*}{ Fuencaliente } & 15.08 .36 & Iglesia parroquial & $\begin{array}{l}\text { Saqueo, destrucción e incendio de imágenes en la } \\
\text { plaza pública. Después, la iglesia fue cuadra de } \\
\text { caballerías, albergue de refugiados y depósito de } \\
\text { chatarra. Destrozado el archivo parroquial, apenas } \\
\text { sobrevivieron algunos libros. }\end{array}$ \\
\hline & 15.08 .36 & Ermita de San Antonio & $\begin{array}{l}\text { Se quemaron las imágenes en la plaza de dicha } \\
\text { ermita. }\end{array}$ \\
\hline $\begin{array}{l}\text { Hinojosas de } \\
\text { Calatrava }\end{array}$ & 25.07 .36 & Iglesia parroquial & $\begin{array}{l}\text { Destrucción, completo saqueo y quema de la iglesia } \\
\text { parroquial y de las imágenes, a las que sacaron los } \\
\text { ojos; los milicianos se vistieron con los ornamentos } \\
\text { del culto. Se quitaron las campanas. En la posguerra } \\
\text { hubo que derribar el templo y construir un edificio } \\
\text { nuevo. Desaparecieron gran parte de los libros del } \\
\text { archivo parroquial. }\end{array}$ \\
\hline Mestanza & 27.07 .36 & Iglesias Parroquiales & $\begin{array}{l}\text { Destrucción de imágenes y objetos de culto. Se } \\
\text { perdieron varios libros del archivo parroquial. }\end{array}$ \\
\hline $\begin{array}{l}\text { Los Pozuelos de } \\
\text { Calatrava }\end{array}$ & ¿?.07.36 & Iglesia parroquial & $\begin{array}{l}\text { Saqueo, destrucción y profanación de imágenes y } \\
\text { objetos de culto. Desaparecen varios libros del } \\
\text { registro parroquial. }\end{array}$ \\
\hline Puertollano & 19.07 .36 & $\begin{array}{l}\text { Ermita de Nuestra Señora } \\
\text { Virgen de la Gracia, Parroquia } \\
\text { de Nuestra Señora de la } \\
\text { Asunción y Ermita de Nuestra } \\
\text { Señora de la Soledad }\end{array}$ & $\begin{array}{l}\text { Asalto, saqueo e incendio de imágenes y objetos de } \\
\text { culto. Se quemó alguna documentación del archivo } \\
\text { parroquial. }\end{array}$ \\
\hline $\begin{array}{l}\text { San Lorenzo de } \\
\text { Calatrava }\end{array}$ & 21.07 .36 & Iglesia parroquial & $\begin{array}{l}\text { Destrucción total del archivo parroquial y } \\
\text { destrucción de imágenes y objetos de culto. El } 26 \\
\text { de julio se saqueó el domicilio particular del } \\
\text { párroco. }\end{array}$ \\
\hline
\end{tabular}




\begin{tabular}{|c|c|c|c|}
\hline Localidad & Fecha & Edificio & Descripción \\
\hline Solana del Pino & ¿?.08.36 & Iglesia parroquial & $\begin{array}{l}\text { Se asaltó la casa del párroco, se destruyeron objetos } \\
\text { religiosos y se sustrajo el mobiliario; se procedió a } \\
\text { la destrucción del archivo parroquial, imágenes, } \\
\text { altares, retablos y objetos de culto. }\end{array}$ \\
\hline $\begin{array}{l}\text { Villamayor de } \\
\text { Calatrava }\end{array}$ & 24.07.36 & Iglesia parroquial & $\begin{array}{l}\text { Incendio de imágenes, objetos y ornamentos } \\
\text { religiosos en la puerta de la iglesia. El registro } \\
\text { parroquial perdió sólo un libro. }\end{array}$ \\
\hline $\begin{array}{l}\text { Villanueva de } \\
\text { San Carlos }\end{array}$ & ¿?.08.36 & $\begin{array}{l}\text { Iglesia parroquial de Nuestra } \\
\text { Señora del Rosario y Ermita } \\
\text { de San Isidro Labrador }\end{array}$ & $\begin{array}{l}\text { Destrucción e incendio de las imágenes y objetos de } \\
\text { culto. El Registro parroquial no sufrió daños. }\end{array}$ \\
\hline \multicolumn{4}{|c|}{ Partido judicial de Ciudad Real } \\
\hline $\begin{array}{l}\text { Ballesteros de } \\
\text { Calatrava }\end{array}$ & ¿?.08.36 & Iglesia parroquial & $\begin{array}{l}\text { Destrucción de las obras de arte, quemando todo y } \\
\text { arrastrando las imágenes por las calles. También } \\
\text { saquearon el domicilio del párroco, recogiendo las } \\
\text { alhajas, cetros y demás que eran propiedad de la } \\
\text { iglesia y la hermandad de la Virgen. El archivo } \\
\text { parroquial no sufrió desperfectos. }\end{array}$ \\
\hline $\begin{array}{l}\text { Cañada de } \\
\text { Calatrava }\end{array}$ & ¿? & Iglesia parroquial & $\begin{array}{l}\text { Se destruyeron imágenes y objetos de culto en el } \\
\text { templo. El registro parroquial no sufrió daños. }\end{array}$ \\
\hline $\begin{array}{l}\text { Carrión de } \\
\text { Calatrava }\end{array}$ & ¿? & $\begin{array}{l}\text { Dos iglesias del pueblo y de la } \\
\text { Ermita de la Virgen }\end{array}$ & $\begin{array}{l}\text { Fueron destruidas las dos iglesias del pueblo y la } \\
\text { Ermita de la Virgen, que se halla fuera del pueblo. } \\
\text { El registro parroquial no sufrió ningún daño. }\end{array}$ \\
\hline \multirow[t]{3}{*}{ Ciudad Real } & ¿? & $\begin{array}{l}\text { Iglesia parroquial de San } \\
\text { Pedro Apóstol }\end{array}$ & Todo su patrimonio fue destruido e incendiado \\
\hline & ¿? & Iglesia de Santiago Apóstol & $\mathrm{El}$ archivo y registro fue destruido totalmente. \\
\hline & ¿? & $\begin{array}{l}\text { Casa e Iglesia del Instituto de } \\
\text { Misioneros Hijos del } \\
\text { inmaculado Corazón de María }\end{array}$ & $\begin{array}{l}\text { Las milicias desvalijaron ambas propiedades de los } \\
\text { ornamentos y objetos de culto, destruyeron los } \\
\text { altares, quemaron las imágenes y convirtieron la } \\
\text { iglesia en salón de cine. }\end{array}$ \\
\hline Chillón & ¿? & $\begin{array}{l}\text { Conjunto de iglesias y } \\
\text { edificios religiosos }\end{array}$ & $\begin{array}{l}\text { Saqueo, profanación y destrucción de las iglesias } \\
\text { locales con robo y destrucción de objetos de culto. }\end{array}$ \\
\hline $\begin{array}{l}\text { Fernán } \\
\text { Caballero }\end{array}$ & ¿? & Iglesia parroquial & $\begin{array}{l}\text { El templo fue destrozado, quemándose los altares, } \\
\text { imágenes y ornamentos de culto. El registro } \\
\text { parroquial fue parcialmente destruido. }\end{array}$ \\
\hline \multirow[t]{3}{*}{ Malagón } & ¿? & Iglesia parroquial & $\begin{array}{l}\text { Se destruyeron las imágenes, el órgano y los } \\
\text { ornamentos de culto. También fueron sustraídas las } \\
\text { campañas. Del archivo parroquial desaparecieron } \\
\text { muchos volúmenes. }\end{array}$ \\
\hline & ¿? & $\begin{array}{l}\text { Convento de las Carmelitas } \\
\text { Descalzas }\end{array}$ & $\begin{array}{l}\text { El inmueble fue convertido en albergue de } \\
\text { evacuados. Se sustrajeron una custodia con aureola } \\
\text { de esmeraldas y otros objetos de culto por valor de } \\
\text { varios millones de pesetas. }\end{array}$ \\
\hline & ¿? & $\begin{array}{l}\text { Santuario del Cristo del } \\
\text { Espíritu Santo }\end{array}$ & Fue destruido. \\
\hline
\end{tabular}




\begin{tabular}{|c|c|c|c|}
\hline Localidad & Fecha & Edificio & Descripción \\
\hline Miguelturra & 23.07 .36 & $\begin{array}{l}\text { Iglesia parroquial, cuatro } \\
\text { ermitas y Convento de las } \\
\text { Monjas Mercedarias. Iglesias } \\
\text { del Santo Cristo, San Antón, } \\
\text { Virgen de la Soledad y Virgen } \\
\text { de la Estrella }\end{array}$ & $\begin{array}{l}\text { Entre julio y octubre de } 1936 \text { fueron saqueadas las } \\
\text { iglesias, con quema de imágenes y objetos de culto. } \\
\text { Del archivo parroquial desaparecieron } 29 \text { libros de } \\
\text { bautismos, } 14 \text { de defunciones e innumerables } \\
\text { expedientes matrimoniales y documentos. }\end{array}$ \\
\hline Poblete & 27.07.36 & $\begin{array}{l}\text { Iglesia parroquial de Santa } \\
\text { María Magdalena }\end{array}$ & $\begin{array}{l}\text { Se quemaron imágenes y se destruyeron y robaron } \\
\text { objetos de culto. El registro parroquial fue destruido } \\
\text { por completo. }\end{array}$ \\
\hline $\begin{array}{l}\text { Torralba de } \\
\text { Calatrava }\end{array}$ & ¿? & $\begin{array}{l}\text { Iglesia parroquial, Parroquia } \\
\text { del Santísimo Cristo del } \\
\text { Consuelo y Ermita de la } \\
\text { Purísima Concepción }\end{array}$ & $\begin{array}{l}\text { Expolio, destrucción y robo de objeto de culto e } \\
\text { imágenes. El archivo parroquial sufrió algunas } \\
\text { pérdidas. }\end{array}$ \\
\hline Villar del Pozo & ¿?.07.36 & Iglesia parroquial & $\begin{array}{l}\text { En los primeros días quitaron todos los santos y } \\
\text { vírgenes de sus altares, convirtieron la iglesia en } \\
\text { almacén de alimentos y carruajes, robaron ropas y } \\
\text { enseres y dejaron hundirse la techumbre. El archivo } \\
\text { parroquial no sufrió ningún deterioro. }\end{array}$ \\
\hline \multicolumn{4}{|c|}{ Partido judicial de Daimiel } \\
\hline $\begin{array}{l}\text { Arenas de San } \\
\text { Juan }\end{array}$ & 23.07.36 & $\begin{array}{l}\text { Iglesia de Nuestra Señora de } \\
\text { las Angustias }\end{array}$ & $\begin{array}{l}\text { Saqueo y destrucción de imágenes y objetos de } \\
\text { culto. Del archivo parroquial desaparecieron varios } \\
\text { libros. }\end{array}$ \\
\hline Daimiel & ¿?.07.36 & $\begin{array}{l}\text { Diez de los once edificios } \\
\text { religiosos }\end{array}$ & $\begin{array}{l}\text { Fueron destruidos completamente, destrozando } \\
\text { imágenes, altares, ornamentos, objetos de culto, y } \\
\text { toda la documentación de sus archivos. Del archivo } \\
\text { parroquial desaparecieron muchos tomos y se } \\
\text { estropearon otros. La iglesia del Convento de los } \\
\text { Pasionistas fue quemada, robada y saqueada. }\end{array}$ \\
\hline Fuente el Fresno & & Nada & No se hallaron desperfectos de consideración. \\
\hline $\begin{array}{l}\text { Villarrubia de } \\
\text { los Ojos }\end{array}$ & 15.08.36 & $\begin{array}{l}\text { Iglesia parroquial, Convento } \\
\text { de las Clarisas, Iglesia de San } \\
\text { Francisco, Capilla de Luisa } \\
\text { Casanova, Capilla del } \\
\text { Cementerio, Capilla de San } \\
\text { Cristóbal y Santuario de } \\
\text { Nuestra Señora de la Virgen } \\
\text { de la Sierra }\end{array}$ & $\begin{array}{l}\text { Se destruyeron todos los retablos e imágenes, } \\
\text { profanando y robando los objetos de culto. Fue } \\
\text { levantado incluso el piso de madera y las puertas de } \\
\text { los templos. La imagen de la Virgen de la Sierra, } \\
\text { patrona de la localidad, fue expoliada de sus joyas y } \\
\text { quemada }\end{array}$ \\
\hline \multicolumn{4}{|c|}{ Partido judicial de Infantes } \\
\hline Albaladejo & & Nada & No se registraron daños de ningún tipo. \\
\hline Alcubillas & ¿?.10.36 & Iglesia parroquial & $\begin{array}{l}\text { Robo e incendio de imágenes, destrozo de altares y } \\
\text { mobiliario, sustracción de las campanas y objetos } \\
\text { de culto. Completamente destruido el interior del } \\
\text { templo, sólo quedaron las paredes. El archivo } \\
\text { parroquial fue completamente destruido. }\end{array}$ \\
\hline
\end{tabular}




\begin{tabular}{|c|c|c|c|}
\hline Localidad & Fecha & Edificio & Descripción \\
\hline Alhambra & 6.08 .36 & Iglesia parroquial & $\begin{array}{l}\text { Robo y quema de imágenes, retablos y objetos de } \\
\text { culto. El archivo parroquial fue quemado. }\end{array}$ \\
\hline Almedina & ¿?.08.36 & $\begin{array}{l}\text { Iglesia parroquial y Ermita de } \\
\text { los Remedios }\end{array}$ & $\begin{array}{l}\text { Destejaron y hundieron las bóvedas de la Parroquia, } \\
\text { destrozaron el retablo y los altares y rompieron las } \\
\text { campanas. El archivo parroquial no sufrió daños. }\end{array}$ \\
\hline Carrizosa & ¿?.08.36 & Iglesia parroquial & $\begin{array}{l}\text { Destrucción de altares y quema de imágenes y } \\
\text { objetos de culto. El archivo parroquial no sufrió } \\
\text { daños. }\end{array}$ \\
\hline Cózar & ¿?.08.36 & Iglesia parroquial & $\begin{array}{l}\text { Destrucción total del interior del templo y destrozo } \\
\text { de los objetos de culto. El archivo parroquial fue } \\
\text { quemado. }\end{array}$ \\
\hline Fuenllana & ¿?.12.36 & $\begin{array}{l}\text { Iglesia parroquial de Santo } \\
\text { Tomás de Villanueva } \\
\text { Ocupación, profanación y } \\
\text { destrucción de imágenes y } \\
\text { enseres }\end{array}$ & $\begin{array}{l}\text { Se profanó y destruyó el templo con sus imágenes y } \\
\text { objetos de culto. }\end{array}$ \\
\hline Infantes & 1.12 .36 & $\begin{array}{l}\text { Iglesia parroquial y demás } \\
\text { templos }\end{array}$ & $\begin{array}{l}\text { Destrucción de todas las imágenes y objetos de } \\
\text { culto en los edificios religiosos. El archivo } \\
\text { parroquial no sufrió daños. }\end{array}$ \\
\hline Montiel & 28.07 .36 & Iglesia parroquial & $\begin{array}{l}\text { Quema y destrucción de imágenes y objetos de } \\
\text { culto. En } 1938 \text { fue quemada extramuros de la } \\
\text { población la venerada imagen del santísimo Cristo } \\
\text { de la Expiración. Desaparecieron varios libros del } \\
\text { archivo parroquial. }\end{array}$ \\
\hline $\begin{array}{l}\text { Puebla del } \\
\text { Príncipe }\end{array}$ & ¿? & Iglesia parroquial & $\begin{array}{l}\text { Destrucción de los retablos, imágenes y objetos de } \\
\text { culto. El archivo parroquial fue parcialmente } \\
\text { destruido. }\end{array}$ \\
\hline $\begin{array}{l}\text { Santa Cruz de } \\
\text { los Cáñamos }\end{array}$ & 30.10 .36 & Iglesia parroquial & $\begin{array}{l}\text { Quema de imágenes y retablos. Sustrajeron las } \\
\text { campanas. Pero el archivo y el registro parroquiales } \\
\text { no sufrieron daños. }\end{array}$ \\
\hline Terrinches & ¿? & $\begin{array}{l}\text { Iglesia parroquial, Ermita de } \\
\text { Nuestra Señora de Luciana, } \\
\text { Ermita de San Antón y Ermita } \\
\text { del Santo Cristo. }\end{array}$ & $\begin{array}{l}\text { Destrucción, robo e incendio de imágenes, altares, } \\
\text { retablos, órganos y objetos de culto. La última } \\
\text { ermita fue derribada en parte, quedando en ruinas. } \\
\text { El registro y el archivo parroquiales no sufrieron } \\
\text { daños. }\end{array}$ \\
\hline $\begin{array}{l}\text { Torre de Juan } \\
\text { Abad }\end{array}$ & ¿?.11.36 & $\begin{array}{l}\text { Iglesia parroquial y Ermita de } \\
\text { la Virgen de la Vega }\end{array}$ & $\begin{array}{l}\text { Destrucción, robo e incendio de imágenes, } \\
\text { mobiliario y objetos de culto. Antes de quemarlas } \\
\text { las imágenes fueron paseadas por las calles. El } \\
\text { registro y el archivo parroquiales no sufrieron } \\
\text { daños. }\end{array}$ \\
\hline Villahermosa & ¿? & $\begin{array}{l}\text { Iglesia parroquial y Ermitas de } \\
\text { San Agustín, Los Dolores, } \\
\text { Santa Ana, Pretorio, Santo } \\
\text { Cristo, La Carrasca e Iglesia } \\
\text { de Cañamares }\end{array}$ & $\begin{array}{l}\text { Destrucción, robo y quema de imágenes, altares, } \\
\text { mobiliario y objetos de culto. El registro y el } \\
\text { archivo parroquiales no sufrieron daños. }\end{array}$ \\
\hline
\end{tabular}




\begin{tabular}{|c|c|c|c|}
\hline Localidad & Fecha & Edificio & Descripción \\
\hline Villamanrique & ¿?.10.36 & Iglesia parroquial & $\begin{array}{l}\text { Destrucción y quema de imágenes, retablos y } \\
\text { objetos de culto, así como la documentación. Sólo } \\
\text { se salvó parte del registro parroquial. }\end{array}$ \\
\hline $\begin{array}{l}\text { Villanueva de la } \\
\text { Fuente }\end{array}$ & 1.11.36 & Iglesia parroquial & $\begin{array}{l}\text { Destrucción del interior del templo y quema de } \\
\text { imágenes. }\end{array}$ \\
\hline \multicolumn{4}{|c|}{ Partido judicial de Manzanares } \\
\hline Las Labores & 15.08 .36 & Iglesia parroquial & $\begin{array}{l}\text { Destrucción de altares, púlpito, retablos y objetos de } \\
\text { culto. El archivo parroquial no sufrió daños. } \\
\text { Seguidamente, la Casa del Pueblo se instaló en el } \\
\text { edificio. }\end{array}$ \\
\hline Manzanares*** & 21.07 .36 & $\begin{array}{l}\text { Iglesia parroquial, Ermita de } \\
\text { Nuestro Padre Jesús del } \\
\text { Perdón, Iglesia de Nuestra Sra. } \\
\text { de Altagracia, Iglesias y } \\
\text { Conventos de las Religiosas } \\
\text { Concepcionistas y } \\
\text { Franciscanas Descalzas, } \\
\text { Iglesia de San Antonio Abad, } \\
\text { Iglesia y Hospital Asilo y Casa } \\
\text { de Caridad, Ermita de Santa } \\
\text { Quiteria, Ermita de San Blas, } \\
\text { Capilla de las Concepcionistas } \\
\text { de María Inmaculada, Capilla } \\
\text { de Nuestra Señora de La } \\
\text { Soledad, Capilla del Santísimo } \\
\text { Cristo de la Agonía, Ermita de } \\
\text { Santa María Magdalena, } \\
\text { Capillas generales y } \\
\text { particulares de los } \\
\text { Cementerios, Capilla del } \\
\text { Calvario y siete oratorios } \\
\text { particulares que existían en } \\
\text { Manzanares }\end{array}$ & $\begin{array}{l}\text { Estos edificios fueron incendiados y destruidos en } \\
\text { diversos grados, con destrozo, saqueo o quema de } \\
\text { imágenes, mobiliario y objetos de culto. Del } \\
\text { archivo parroquial desaparecieron muchos libros. }\end{array}$ \\
\hline \multirow[t]{3}{*}{ Membrilla } & 21.07 .36 & Iglesia parroquial & $\begin{array}{l}\text { El edificio fue incendiado y quemados todos los } \\
\text { objetos de culto. El archivo parroquial fue } \\
\text { totalmente destruido. }\end{array}$ \\
\hline & 24.07 .36 & $\begin{array}{l}\text { Santuario de Nuestra Señora } \\
\text { del Espino y Ermita de } \\
\text { Nuestra Señora de la Soledad }\end{array}$ & $\begin{array}{l}\text { El edificio fue incendiado y quemados todos los } \\
\text { objetos de culto e imágenes. }\end{array}$ \\
\hline & 27.07 .36 & $\begin{array}{l}\text { Convento de las Religiosas } \\
\text { Franciscanas }\end{array}$ & $\begin{array}{l}\text { Destrucción de todo el edificio y de su iglesia con } \\
\text { todos los objetos de culto. }\end{array}$ \\
\hline $\begin{array}{l}\text { San Carlos del } \\
\text { Valle }\end{array}$ & 25.07 .36 & $\begin{array}{l}\text { Parroquia del Santísimo Cristo } \\
\text { del Valle }\end{array}$ & $\begin{array}{l}\text { En julio se ocupó el edificio pero fue el } 20 \text { de } \\
\text { agosto cuando se procedió a la destrucción de } \\
\text { imágenes, órganos, púlpito y demás objetos } \\
\text { litúrgicos. En octubre se expoliaron las campanas. } \\
\text { El archivo parroquial fue destruido el } 20 \text { de agosto } \\
\text { de } 1936 .\end{array}$ \\
\hline
\end{tabular}




\begin{tabular}{|c|c|c|c|}
\hline Localidad & Fecha & Edificio & Descripción \\
\hline \multirow[t]{2}{*}{ La Solana } & 23.07.36 & $\begin{array}{l}\text { Iglesia parroquial de Santa } \\
\text { Catalina }\end{array}$ & $\begin{array}{l}\text { Destrucción de altares, retablos, imágenes, objetos } \\
\text { de culto y el archivo parroquial al completo. El día } \\
25 \text { fue quemada la cúpula de la torre y el tejado de } \\
\text { la iglesia. Sólo quedaron en pie las murallas. Las } \\
\text { campanas también se sustrajeron con fines bélicos. }\end{array}$ \\
\hline & 25.07.36 & $\begin{array}{l}\text { Iglesias del Cristo del Amor y } \\
\text { del Convento de los } \\
\text { Trinitarios, y Ermitas de Santa } \\
\text { Quiteria, San Sebastián y El } \\
\text { Calvario }\end{array}$ & $\begin{array}{l}\text { Fueron incendiadas las iglesias, quemaron las } \\
\text { imágenes y destruyeron o robaron cuantos objetos } \\
\text { de culto encontraron. La iglesia del Convento de los } \\
\text { Trinitarios fue dinamitada en 1937, quedando sólo } \\
\text { en pie algunos muros del edificio. La iglesia del } \\
\text { Convento de las Dominicas fue destinada a cárcel y, } \\
\text { después, a albergue de evacuados. }\end{array}$ \\
\hline $\begin{array}{l}\text { Villarta de San } \\
\text { Juan }\end{array}$ & & Nada & El registro parroquial sufrió «poco daño». \\
\hline \multicolumn{4}{|c|}{ Partido judicial de Piedrabuena } \\
\hline $\begin{array}{l}\text { Alcoba de los } \\
\text { Montes }\end{array}$ & ¿?.11.36 & Iglesia parroquial & $\begin{array}{l}\text { En noviembre o diciembre de } 1936 \text { se saquearon } \\
\text { los objetos de valor. En septiembre de } 1937 \text { se } \\
\text { quemaron con gasolina las imágenes y los objetos } \\
\text { de culto. Se extrajeron las campanas. }\end{array}$ \\
\hline $\begin{array}{l}\text { Alcolea de } \\
\text { Calatrava }\end{array}$ & ¿?.08.36 & Iglesia parroquial & $\begin{array}{l}\text { Quema de imágenes, ropa, retablo y ornamentos de } \\
\text { culto. Del archivo parroquial desaparecieron varios } \\
\text { libros de bautismos, matrimonios, defunciones, } \\
\text { confirmaciones, etc. }\end{array}$ \\
\hline Anchuras & ¿?.08.36 & Iglesia parroquial & $\begin{array}{l}\text { Se saqueó el templo, con destrucción de altares y } \\
\text { quema de imágenes y objetos de culto. El registro } \\
\text { parroquial quedó intacto. }\end{array}$ \\
\hline $\begin{array}{l}\text { Arroba de los } \\
\text { Montes }\end{array}$ & 10.11.36 & Iglesia parroquial & $\begin{array}{l}\text { Milicianos de Ciudad Real se llevan las campanas. } \\
\text { Meses antes los vecinos se llevaron a sus casas las } \\
\text { imágenes de la parroquia y consiguieron } \\
\text { preservarlas hasta el final de la guerra. }\end{array}$ \\
\hline Fontanarejo & ¿? & Iglesia parroquial & $\begin{array}{l}\text { Sustracción de campanas a cargo de unos } \\
\text { forasteros. }\end{array}$ \\
\hline $\begin{array}{l}\text { Horcajo de los } \\
\text { Montes }\end{array}$ & ¿?.08.36 & Iglesia parroquial & $\begin{array}{l}\text { Destrucción de las imágenes y objetos de culto. El } \\
\text { edificio no sufrió daños. }\end{array}$ \\
\hline Luciana & ¿? & Iglesia parroquial & $\begin{array}{l}\text { Destrucción de imágenes, objetos de culto, retablos, } \\
\text { altares y archivo parroquial. }\end{array}$ \\
\hline Navalpino & ¿?.11.36 & Iglesia parroquial & $\begin{array}{l}\text { Unos forasteros se llevaron las campanas y otros } \\
\text { objetos de metal. }\end{array}$ \\
\hline Navas de Estena & ¿?.08.36 & Iglesia parroquial & $\begin{array}{l}\text { Destinada a almacén, luego fue incendiada en } \\
\text { agosto y quedó totalmente destruida. }\end{array}$ \\
\hline Picón & ¿? & Iglesia parroquial & $\begin{array}{l}\text { Quema y destrucción de imágenes, objetos de culto, } \\
\text { altares y algunos retablos. }\end{array}$ \\
\hline
\end{tabular}




\begin{tabular}{|c|c|c|c|}
\hline Localidad & Fecha & Edificio & Descripción \\
\hline Piedrabuena & 23.08 .36 & $\begin{array}{l}\text { Iglesia parroquial y Ermitas de } \\
\text { San Bartolomé y de la Santa } \\
\text { Cruz. }\end{array}$ & $\begin{array}{l}\text { Quema de imágenes y expolio de las campanas. Del } \\
\text { templo parroquial sólo quedaron la techumbre y las } \\
\text { paredes. También se llevaron las campanas. En el } \\
\text { archivo parroquial desaparecieron algunos libros de } \\
\text { confirmaciones. }\end{array}$ \\
\hline Porzuna & ¿?.09.36 & Iglesia parroquial & $\begin{array}{l}\text { Saqueo, destrucción y quema de objetos de culto, } \\
\text { cuadros e imágenes. El local se utilizó como } \\
\text { almacén, cárcel y establo, sucesivamente. } \\
\text { Desaparecieron algunos libros del archivo } \\
\text { parroquial. }\end{array}$ \\
\hline $\begin{array}{l}\text { Puebla de don } \\
\text { Rodrígo }\end{array}$ & ¿? & Iglesia parroquial & $\begin{array}{l}\text { Saqueo y destrucción de imágenes y objetos de } \\
\text { culto. Sustracción de las campanas. El archivo y el } \\
\text { registro parroquial fueron destruidos por completo. }\end{array}$ \\
\hline $\begin{array}{l}\text { Retuerta del } \\
\text { Bullaque }\end{array}$ & ¿? & Iglesia parroquial & $\begin{array}{l}\text { Destrucción de imágenes y sustracción de las } \\
\text { campanas. Del archivo parroquial desaparecieron } \\
\text { algunos folios de algunos libros. }\end{array}$ \\
\hline \multicolumn{4}{|c|}{ Partido judicial de Valdepeñas } \\
\hline Almuradiel & 8.08 .36 & Iglesia parroquial & $\begin{array}{l}\text { Destrucción y quema de objetos de culto, altares e } \\
\text { imágenes. }\end{array}$ \\
\hline $\begin{array}{l}\text { Castellar de } \\
\text { Santiago }\end{array}$ & 28.07 .36 & Iglesia parroquial & $\begin{array}{l}\text { Destrucción de altares, retablos, púlpitos y } \\
\text { escaleras, y quema y robo de imágenes y objetos de } \\
\text { culto en el exterior. }\end{array}$ \\
\hline $\begin{array}{l}\text { Moral de } \\
\text { Calatrava }\end{array}$ & ¿?.08.36 & Todos los templos locales & $\begin{array}{l}\text { Destrucción de imágenes y objetos de culto, y } \\
\text { expolio de las joyas y objetos artísticos. }\end{array}$ \\
\hline $\begin{array}{l}\text { Santa Cruz de } \\
\text { Mudela }\end{array}$ & 26.07 .36 & $\begin{array}{l}\text { Iglesia parroquial, Ermita de } \\
\text { San José, Casa de los } \\
\text { Hermanos de la Doctrina } \\
\text { Cristiana, Colegio de la } \\
\text { Concepción, Ermita de San } \\
\text { Sebastián, Ermita de San } \\
\text { Roque, Ermita de Nuestra } \\
\text { Señora de las Virtudes, Capilla } \\
\text { del Balneario Cervantes, } \\
\text { Capilla del Castillo de Mudela } \\
\text { y un oratorio particular }\end{array}$ & $\begin{array}{l}\text { En la parroquia se quitaron las imágenes, el órgano } \\
\text { y los objetos de culto; luego fueron quemadas en el } \\
\text { mismo templo. Mismo proceso en los otros templos } \\
\text { y capillas. El archivo parroquial fue quemado y } \\
\text { destrozado. }\end{array}$ \\
\hline Torrenueva & ¿? & $\begin{array}{l}\text { Iglesia parroquial y Ermitas de } \\
\text { la Veracruz, San Juan, San } \\
\text { Antón, Santo Cristo y Ermita } \\
\text { de la Patrona }\end{array}$ & $\begin{array}{l}\text { Destrucción y quema de imágenes y objetos de } \\
\text { culto. La Parroquia fue la sede de la Casa del } \\
\text { Pueblo. }\end{array}$ \\
\hline Valdepeñas & ¿? & $\begin{array}{l}\text { Conjunto de templos y } \\
\text { edificios religiosos }\end{array}$ & $\begin{array}{l}\text { Saqueo, destrucción y quema de imágenes y objetos } \\
\text { de culto. Aunque no hubo incendios, no quedó } \\
\text { ningún local en condiciones de dedicarse al culto. } \\
\text { La Ermita de San Juan fue incluso demolida. }\end{array}$ \\
\hline
\end{tabular}




\begin{tabular}{|l|c|l|l|}
\hline \multicolumn{1}{|c|}{ Localidad } & Fecha & \multicolumn{1}{c|}{ Edificio } & \multicolumn{1}{c|}{ Descripción } \\
\hline $\begin{array}{l}\text { Viso del } \\
\text { Marqués }\end{array}$ & $i ?$ & $\begin{array}{l}\text { Iglesia parroquial, Convento } \\
\text { de las Hermanas Mercedarias } \\
\text { y Ermitas de Nuestra Señora } \\
\text { de los Dolores y de las } \\
\text { haciendas de Mudela y de } \\
\text { Fresnedas }\end{array}$ & $\begin{array}{l}\text { Saqueo y demolición del interior de estos edificios; } \\
\text { destrucción y quema de imágenes y ornamentos de } \\
\text { culto. Los edificios se destinaron a garajes, } \\
\text { almacenes, cuadras, etc. }\end{array}$ \\
\hline
\end{tabular}

Fuente: AHN, Fondos Contemporáneos, Causa General, legs. 1027, 1028, 1029, 1030 y 1033. Elaboración propia.

\section{Comentarios:}

* En Almodóvar del Campo, otras cinco aldeas-pedanías sufrieron daños parciales o totales en sus archivos parroquiales.

** De Corral de Calatrava no consta el número de iglesias afectadas pero se han detectado 1 parroquia y 2 ermitas en la red.

*** Posiblemente, Manzanares fue el caso más espectacular de toda la provincia en cuanto a destrucción de los templos. A las 15 iglesias y/o ermitas afectadas se sumaron siete oratorios particulares.

\section{Bibliogr AFÍA}

Albertí, Jordi, La Iglesia en llamas. La persecución religiosa en España durante la Guerra Civil, Barcelona, Destino, 2008.

Alía Miranda, Francisco, La Guerra Civil en Ciudad Real, 1936-1939. Conflicto y revolución en una provincia de la retaguardia republicana, Ciudad Real, Diputación, 2017.

Anuario Estadístico Provincial de Ciudad Real. Año 1946, Madrid, INE, 1947.

Braud, Philippe, Violencias políticas, Madrid, Alianza Editorial, 2006.

Cárcel Ortí, Vicente, La persecución religiosa en España durante la Segunda República (1931-1939), Madrid, Rialp, 1990.

Cárcel Ortí, Vicente, Mártires españoles del siglo XX, Madrid, BAC, 1995.

Cárcel Ortí, Vicente, La gran persecución. España 1931-1939, Barcelona, Planeta, 2000.

Cárcel Ortí, Vicente, Caídos, víctimas y mártires. La Iglesia y la hecatombe de 1936, Madrid, Espasa Calpe, 2008.

Casanova, Julián, La Iglesia de Franco, Madrid, Temas de Hoy, 2001.

Castro Alfín, Demetrio, «Cultura, política y cultura política en la violencia anticlerical», en Rafael Cruz y Manuel Pérez Ledesma (eds.), Cultura y movilización en la España contemporánea, Madrid, Alianza Universidad, 1997: 69-97.

Castro Alfín, Demetrio, «Palabras de fuego. El anticlericalismo republicano», Journal of Spanish Cultural Studies, 6/2 (Londres, 2005): 205-226.

Cueva Merino, Julio de la, «El anticlericalismo en la Segunda República y en la Guerra Civil», en Emilio La Parra López y Manuel Suárez Cortina (eds.): El anticlericalismo español contemporáneo, Madrid, Biblioteca Nueva, 1998: 211-301. 
Delgado Ruiz, Manuel, La ira sagrada. Anticlericalismo, iconoclastia y antirritualismo en la España contemporánea, Barcelona, Humanidades, 1992.

Gentile, Emilio, «The sacralization of politics: definitions, interpretations and reflections on the question of secular religion and totalitarianism», Totalitarian movements and political religions, 1/1 (Londres, 2000): 18-55.

Gentile, Emilio, Le religioni della política. Fra democrazie e totalitarismi, Roma/ Bari, Laterza, 2001.

Jiménez Manzanares, José, Martirologio Diocesano, Ciudad Real, Editorial Calatrava, 1947.

Ledesma Vera, José Luis, Delenda est Ecclesia. De la violencia anticlerical y la Guerra Civil de 1936, Madrid, Instituto Universitario Ortega y Gasset, 2009.

Ledesma Vera, José Luis, «Enemigos seculares. La violencia anticlerical (1936-1939)», en Julio de la Cueva Merino y Feliciano Montero García (eds.), Izquierda obrera y religión en España (1900-1939), Alcalá de Henares, Universidad de Alcalá, 2012: 219-244.

Lincoln, Bruce, «Exhumaciones revolucionarias en España, julio 1936», Historia Social, 35 (Valencia, 1999): 101-118.

Martín Nieto, Isaac, Castilla libre. Anarquistas y campesinos en Castilla La Nueva durante la Guerra Civil española (1936-1939), tesis doctoral de Facultad de Geografía e Historia de la Universidad de Salamanca, 2019 (cortesía del autor).

Martín Rubio, Ángel David, «La persecución religiosa en España (1931-1939). Una aportación sobre las cifras», Hispania Sacra, 53 (Madrid, 2001): 63-89.

Martín Rubio, Ángel David, La cruz, el perdón y la gloria: persecución religiosa en España durante la II República y la Guerra Civil, Madrid, Ciudadela Libros, 2007.

Montero Moreno, Antonio, Historia de la persecución religiosa en España, 19361939, Madrid, BAC, 1998.

Payne, Stanley G., 40 preguntas fundamentales sobre la Guerra Civil, Madrid, La Esfera de los Libros, 2006.

Pérez Ledesma, Manuel, "Anticlericalismo y secularización en España», en Antonio Morales Moya (coord.), Las claves de la España del siglo XX. La Cultura, Madrid, Sociedad Estatal España Nuevo Milenio, 2001: 269-285.

Prado Sánchez-Cambronero, Juan Francisco, Conflictividad social y patrimonio en la provincia de Ciudad Real durante la II República (1931-1939), Ciudad Real, Diputación, 2018.

Raguer, Hilari, La pólvora y el incienso. La Iglesia y la guerra civil española (19361939), Barcelona, Península, 2001.

Ranzato, Gabriele, «Dies irae: la persecuzione religiosa nella zona republicana durante la Guerra civile spagnola (1936-1939)», en Gabriele Ranzato: La difficile modernità e altri scritti sulla storia della Spagna contemporanea, Turín, Edizioni dell'Orso, 1997: 147-187.

Rey Reguillo, Fernando del, Paisanos en lucha. Exclusión política y violencia en la Segunda República española, Madrid, Biblioteca Nueva, 2009.

Rey Reguillo, Fernando del, Retaguardia roja. Violencia revolucionaria en la guerra civil española (1936-1939), Barcelona, Galaxia Gutenberg, 2019.

Romero Velasco, Antonio, Historia de la Villa de La Solana, La Solana, Imprenta Posadas, 1940. 
Saavedra Arias, Rebeca, «La destrucción del patrimonio artístico durante la Guerra Civil. El caso cántabro», en Miguel Ángel Aramburu-Zabala et al., Patrimonio destruido en Cantabria, Santander, Universidad de Cantabria, 2012: 49-106.

Saavedra Arias, Rebeca, Destruir y proteger. El patrimonio histórico-artístico durante la Guerra Civil (1936-1939), Santander, Ediciones de la Universidad de Cantabria, 2016.

Suárez Cortina, Manuel (ed.), Secularización y laicismo en la España contemporánea, Santander, Sociedad Menéndez Pelayo, 2001.

Suárez Cortina, Manuel, Entre cirios y garrotes. Política y religión en la España contemporánea, 1808-1936, Santander, Universidad de Cantabria, 2014.

Thomas, María, La fe y la furia: violencia anticlerical popular e iconoclastia en España, 1931-1936, Granada, Comares, 2014.

Vincent, Mary, «"Las llaves del reino”. Violencia religiosa en la Guerra Civil española, julio-agosto de 1936», en Chris Ealham y Michael Richards (eds.), España fragmentada. Historia cultural y Guerra Civil española, Granada, Comares, 2010: 91-119.

Recibido: 02/05/2019

Aceptado: 31/01/2020 